\title{
Kelyphite Rims on Garnets of Contrast Parageneses in Mantle Xenoliths from the Udachnaya-East Kimberlite Pipe (Yakutia)
}

\author{
Lyudmila Pokhilenko
}

Citation: Pokhilenko, L. Kelyphite Rims on Garnets of Contrast

Parageneses in Mantle Xenoliths from the Udachnaya-East Kimberlite Pipe (Yakutia). Minerals 2021, 11, 615. https://doi.org/10.3390/ $\min 11060615$

Academic Editor: Alexandre V. Andronikov

Received: 11 May 2021

Accepted: 3 June 2021

Published: 8 June 2021

Publisher's Note: MDPI stays neutral with regard to jurisdictional claims in published maps and institutional affiliations.

Copyright: (C) 2021 by the author. Licensee MDPI, Basel, Switzerland. This article is an open access article distributed under the terms and conditions of the Creative Commons Attribution (CC BY) license (https:// creativecommons.org/licenses/by/ $4.0 /)$.
V.S. Sobolev Institute of Geology and Mineralogy of the Siberian Branch of the RAS, 3, Ac. Koptyuga Ave., 630090 Novosibirsk, Russia; lu@igm.nsc.ru; Tel.: +7-91-3717-5391

\begin{abstract}
A new classification of kelyphitic rims on garnets from xenoliths of peridotitic and eclogitic parageneses of the mantle section under the Udachnaya-East kimberlite pipe (Yakutia) is presented. Five types of rims are identified: Rim1 develops between garnet and olivine/pyroxene (or rim2) and is composed of high-alumina pyroxenes, spinel, phlogopite; rim2, the coarse grain part of rim1, is located between rim1 and olivine/pyroxene, and mainly consists of phlogopite and less aluminous larger pyroxenes and spinel; rim3 develops between garnet and kimberlite, and presents with phlogopite and Fe-Ti spinel; rim4 sometimes presents instead of rim1/rim2 and consists of zoned high-Cr phlogopite with rare fine grains of chromium spinel; rim5, a "pocket" between garnet and rim1, is represented by microcrystalline aggregates of clinopyroxene, mica, spinel, calcite, and feldspar in different variations. Rims 1,2, and 3 are typical for garnets of all studied parageneses. Rims 4 and 5 develop on high-Cr subcalcic garnets of the most depleted peridotites. Reactions of the formation of all types of rims are given in the article. Each type of kelyphite demonstrates a clear enrichment with a certain component: Rim1- $\mathrm{MgO}$ and alkalis; rim2- $\mathrm{TiO}_{2}$; $\mathrm{rim} 3-\mathrm{FeO}$ and $\mathrm{TiO}_{2} ; \mathrm{rim} 4-\mathrm{Cr}_{2} \mathrm{O}_{3}$; and $\mathrm{rim} 5-\mathrm{CaO}$, suggesting the multistage injection of different components by mantle fluid.
\end{abstract}

Keywords: kelyphite rim; megacrystalline peridotite; sheared peridotite; high-alumina pyroxene; metasomatism

\section{Introduction}

The first mentions of peridotite garnet rims appeared in the mid-19th century [1-3] The term "kelyphite" was first used by Schrauf [4], who considered it a single mineral phase. The same name was used by Hezner [5] to describe the crown around garnets from eclogites. The history of the study of kelyphite rims is reported in detail by Godard and Martin [6]. Kelyphite rims were observed on several minerals, but most often this term is applied to fine-grained aggregates forming around the garnet, which is relevant in the context of this article. In a detailed review article, Obata [7] characterizes kelyphite as a fi-ne-grained fibrous intergrowth of pyroxene, spinel, and amphibole that surrounds garnet. Most studies of kelyphite rims surrounding garnet from metamorphic terrane rocks [6-9] postulate that the formation of these symplectites is the result of a reaction between garnet and adjacent minerals (olivine, quartz, pyroxene) during decompression. At the same time, researchers of kelyphitic rims on garnets from granulites of the BakonyBalaton volcano [10] and alkaline basalts of Liaoning and Shandong provinces (China) [11] concluded that the transformation of garnet into symplectites is an isochemical destruction caused by a rapid increase in temperature and a decrease in pressure. Thus, since the last century [12], most researchers have considered decompression to be an important factor in the formation of the rim surrounding the garnet.

Kelyphite rims on garnets were reported in peridotite-pyroxenite intrusions in the Bohemian Massif [13-16] and in mantle xenoliths of alkaline-ultramafic intrusions, kimberlites, and kimberlite-hosted garnets from different regions globally [16-20]. Using data on a representative collection of samples from the kimberlite regions of the central and marginal 
parts of the Siberian Platform, Kharkiv and Vishnevsky [16] concluded that the isochemical formation of the rims surround peridotite garnets. In addition, they emphasized the presence of significant differences between the features of kelyphitization of garnets from xenoliths and kimberlite cement (dominance of clino- and orthopyroxenes and chromium spinel in the rim composition in the first case, and the predominance of hydrous phases (phlogopite) in the second), confirming the conclusion of Ilupin and his co-authors [21] on the different origins of such rims.

It can be seen from the above that there are two main points of view on the origin of kelyphite rims: (1) As a result of the reaction of garnet and the mineral in contact with it, and (2) as a result of garnet decomposition under the influence of changing conditions. In both cases, fluid exposure is allowed.

All researchers of kelyphite rims on garnets from different petrological settings emphasize that the development of kelyphite occurs inward from the garnet grains and the symplectite structure is normal to the reaction front. Bulk chemical analysis $[6,7,22,23]$ shows that kelyphites generally retain the stoichiometry of garnet due to the decomposition through which they are formed.

In this article, I classify kelyphite rims surrounding garnets of a new collection of fresh upper mantle xenoliths of three contrasting parageneses from the Udachnaya-East kimberlite pipe (Yakutia): Megacrystalline harzburgites and dunites (hereafter, MHD), sheared peridotites (hereafter, ShP), and eclogites (hereafter, Ecl). I carry out a comparative analysis of the rims' composition and structure to elucidate the processes leading to the kelyphite formation. The kelyphite rims on the garnets of the most depleted mantle peridotites, which are weakly subject to metasomatic effects, have not been previously described in the literature. Therefore, these rims are discussed in more detail than the rims on other parageneses garnets. A comparison of the mineral composition, chemical composition of minerals, and structure of kelyphitic rims in enriched and depleted peridotites, and eclogites of a wide range of compositions, makes it possible to reveal their specific features and tendencies common for all parageneses, leading to the formation of different types of kelyphite rims.

\section{Methods, Samples, and Abbreviations}

The studied collection comprised thirty-seven MHD, eight ShP, and sixteen Ecl samples. MHD are the most depleted peridotites of the lithospheric mantle, e.g., [24]. They are mainly composed of large olivine crystals (up to $10 \mathrm{~cm}$ ) and small portions (a total of $<10 \%$ ) of subcalcium high-chromium pyrope (dunite) and sometimes orthopyroxene (harzburgite) (Figure 1a,b). High-chromium chromite, and diamond, can be present in rocks of this type. Garnets have typically very thin kelyphite rims or none. Therefore, the samples analyzed in this study represent the most metasomatized rocks from the most depleted mantle peridotites. The garnets from MHD show quite high contents of $\mathrm{Cr}_{2} \mathrm{O}_{3}$ (10.1 wt.\% on average), $\mathrm{Mg}$ \# ratios (84.6), and low $\mathrm{CaO}$ (3.16 wt.\% on average) and $\mathrm{TiO}_{2}$ (0.06 wt.\% on average) [25]. ShP, on the contrary, are the most enriched mantle peridotites. Coarse-grained porphyroblasts of olivine, orthopyroxene, garnet, and clinopyroxene set in a fine-grained matrix of olivine neoblasts are observed in ShP (Figure 1c). Garnet porphyroblasts have an isometric rounded form and could reach up to $10 \mathrm{~mm}$ in size and have typically thick kelyphitic rims. Compared to pyropes of depleted peridotites (MHD), pyropes of enriched peridotites (ShP) contain lower $\mathrm{Cr}_{2} \mathrm{O}_{3}$ (5.9 wt.\% on average) and $\mathrm{Mg} \#$ (83.5), but higher $\mathrm{CaO}$ (5.4 wt.\% on average) and $\mathrm{TiO}_{2}(0.5 \mathrm{wt} . \%$ on average) [26]. Ecl are mostly bimineral rocks, consisting of a garnet and clinopyroxene, some contain corundum, quartz (or coesite), kyanite, rutile, and diamond. The studied suite of samples is represented by eclogites of a wide range of compositions and different types of textures. The most frequently used upper mantle eclogite classifications are those of Coleman et al. [27] (ratio of pyrope-almandine-grossular (Prp-Alm-Grs) components in garnet), Taylor and Neal [28] (ratio of $\mathrm{MgO}-\mathrm{Na}_{2} \mathrm{O}$ in primary clinopyroxene), MacGregor and Carter [29], and McCandless and Gurney [30] (for bimineral eclogites: Rock texture and ratio of $\mathrm{K}_{2} \mathrm{O}$ in clinopyroxene and $\mathrm{Na}_{2} \mathrm{O}$ in garnet). 

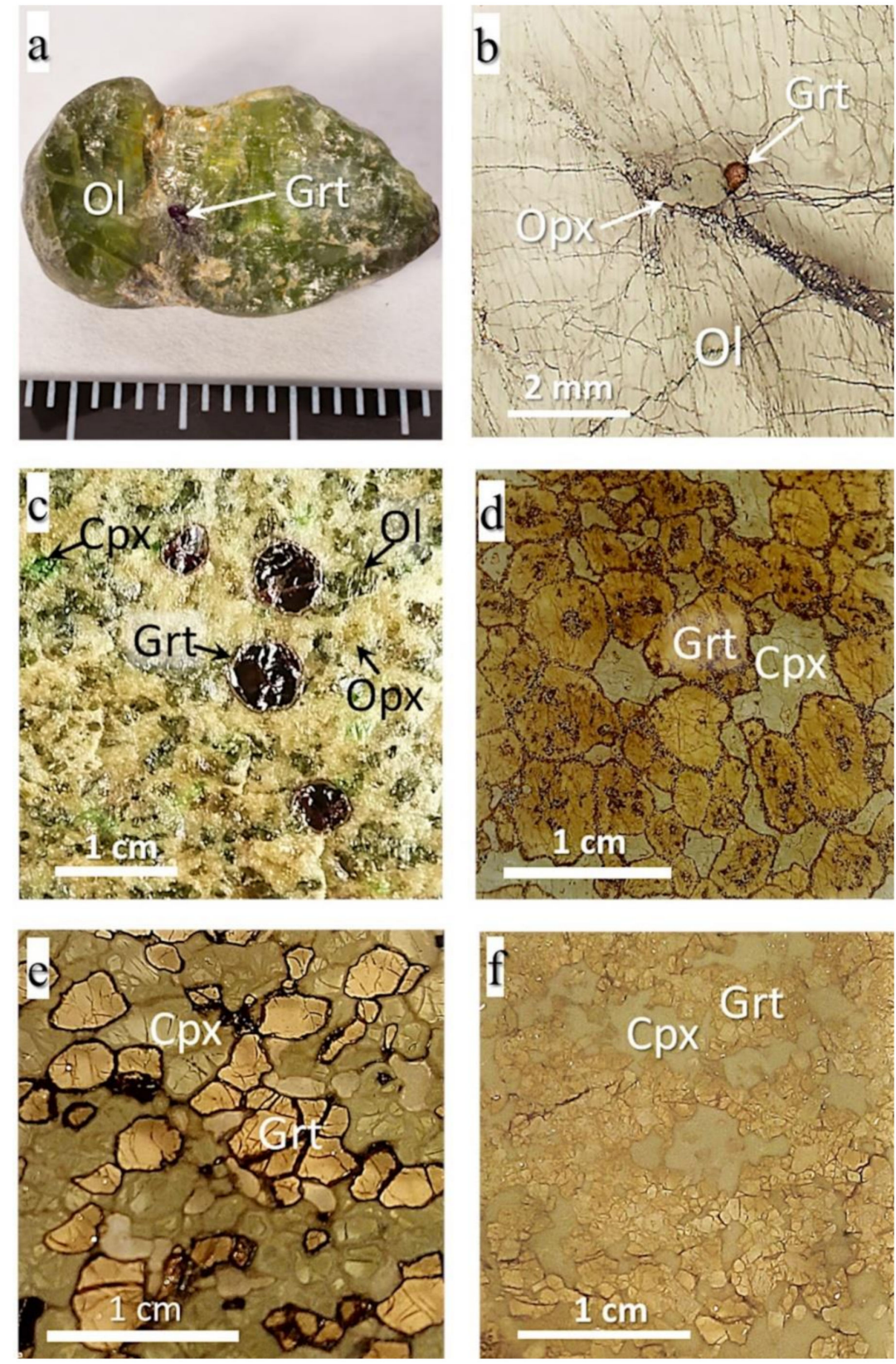

Figure 1. Upper mantle rock xenoliths from Udachnaya kimberlite: (a) General view of megacrystalline dunite; (b) fragment of megacrystalline harzburgite; (c) fragment of fresh sheared lherzolite; (d) typical group A eclogite with equigranular to poikiloblastic texture; (e) typical group B eclogite with medium-grained, granoblastic texture; (f) group C eclogite with nonequidimensionally grained granoblastic texture.

In the context of this article, I have given preference to the classification based on a garnet composition [27]. The compositions of garnets from A, B, and C Ecl from this study collection consisting mainly of pyrope, almandine, and grossular are, respectively, $\operatorname{Prp}_{54-69} \mathrm{Alm}_{13-29} \mathrm{Grs}_{2-20}$, $\operatorname{Prp}_{33-52} \mathrm{Alm}_{18-39} \mathrm{Grs}_{16-35}$, and $\operatorname{Prp}_{0-27} \mathrm{Alm}_{7-38} \mathrm{Grs}_{30-80}$ [31]. Group A Ecl (Figure 1d) consists of orange- to red-colored garnet and light green clinopyroxene. These rocks are coarse-grained with variable textures from equigranular to poikiloblastic. All garnets have kelyphite rims up to 100-250 $\mu \mathrm{m}$ wide. Group B Ecl (Figure 1e) have a coarse- to medium-grained, granoblastic texture. Orange garnet porphyroblasts of 1-8 $\mathrm{mm}$ in size are unequally distributed through the samples. Rims around garnet are cryptocrystalline intergrowths of micron-sized (rarely up to $20 \mu \mathrm{m}$ ) minerals. Group C Ecl 
(Figure 1f) usually contain quartz (or coesite), kyanite, and corundum along with garnet and clinopyroxene. These eclogites are diverse in their textures, primarily due to grain size: Medium- and coarse-grained samples are present. Equidimensionally and nonequidimensionally grained textures are also present. Some samples have a poikiloblastic texture. The kelyphitic rims in the Group C samples are weakly developed compared to the samples in the other eclogite groups.

In this study, rare accessories are mentioned. Djerfisherite (potassium Cl-bearing sulfide: $\mathrm{K}_{6} \mathrm{Na}(\mathrm{Fe}, \mathrm{Ni}, \mathrm{Cu})_{24} \mathrm{~S}_{26} \mathrm{Cl}$ ), tetraferryphlogopite (phlogopite with ferric iron in alumina position: $\mathrm{KMg}_{3} \mathrm{Fe}^{3+} \mathrm{Si}_{3} \mathrm{O}_{10}(\mathrm{OH})_{2}$ ), and baritocelestite (mineral of the isomorphic series between barite $\mathrm{BaSO}_{4}$ and celestite $\mathrm{SrSO}_{4}$ ) are part of a wide suite of accessory minerals recognized in mantle rock xenoliths and kimberlites of the Siberian craton [32-36].

Plane-parallel plates with a thickness of 60-90 microns were prepared from the selected xenoliths. This made it possible to view samples under an optical microscope and analyze minerals. The chemical analysis of minerals was carried out at the Analytical Center for multi-elemental and isotope research, SB RAS, using an electron probe (EMPA; operator: V.N. Korolyuk) and scanning electron microscopy (SEM; operator: M.V. Khlestov). The data obtained by these methods are consistent among themselves for the main components. A JXA-8100 electron microprobe (JEOL, Tokyo, Japan) used an acceleration voltage of $20 \mathrm{kV}$ and a focused beam with a current of 10-30 nA. The total time for recording intensities at the peak of lines and at the points of background measurement was 20-80 s. For each element, the time was chosen so that the detection limit of the component for the one-sided $1 \sigma$ criterion (the confidence level of the component detection was $84 \%$ ) did not exceed 0.01-0.02 wt.\%. Natural minerals and synthetic phases from the collection of the Institute's standards were used as reference specimens. The analysis included the determination of components $\mathrm{SiO}_{2}$ (0.01), $\mathrm{TiO}_{2}(0.015), \mathrm{Al}_{2} \mathrm{O}_{3}(0.015), \mathrm{Cr}_{2} \mathrm{O}_{3}(0.006), \mathrm{FeO}(0.008), \mathrm{MnO}(0.008)$, $\mathrm{MgO}$ (0.02), $\mathrm{CaO}$ (0.006), $\mathrm{Na}_{2} \mathrm{O}$ (0.02), $\mathrm{K}_{2} \mathrm{O}(0.005), \mathrm{Cl}(0.009)$, and $\mathrm{NiO}(0.008)$, for which the detection limit is given in parentheses, wt.\%. The method allows the high accuracy determination of a mineral with a size of 6-7 microns. When analyzing smaller phases, problems can arise. The first of these is caused by the displacement of the electron probe beam from the center of the phase. To avoid this problem, small grains $(2-3 \mu \mathrm{m})$ were enlarged $(300,000 \times)$, then the intensities were measured. The analysis was practically carried out in the "point" mode. The method of converting the measured intensities into the content of oxides was ZAF correction (based on the atomic number (Z), absorption effect (A) and fluorescence effect (F)). Another issue is associated with the scattering of the electron beam ( $\sim$ micron wide) under the analyzed surface. The cross-scattering region may exceed the size of the analyzed phase (here, the mineral grains of the kelyphite rim surrounding the garnet). In this case, values of some components may be overestimated or underestimated. To minimize such an analysis error, each type of mineral grain was analyzed several times in different areas of the rim. The data were averaged. Because the ZAF calculations are sensitive to the presence of hydrogen, the presence of water was considered when determining the composition of hydrous minerals (phlogopite, amphibole, etc.). The microanalysis technique was described in detail earlier [37]. A MIRA 3 LMU (Tescan Orsay Holding, Brno, Czech Republic) scanning electron microscope with microanalysis system INCA Energy 450 + Xmax 80 (Oxford Instruments Nanoanalysis Ltd., High Wycombe, UK) at an accelerating voltage of $20 \mathrm{kV}$, and a counting time of 20-30 s, has an error in determining the main components of no more than 1 rel. \%, and the error for components with concentrations of $1-10 \mathrm{wt}$. \% lies within the range $2-6 \mathrm{rel} . \%$. The method is described in detail in [38]. Bulk composition of the rims was performed using both above methods by applying a defocused electron beam with a diameter of 10-100 microns. The rim was analyzed in several places (2-7), and the result was averaged. Trace elements for MHD were measured in garnets (thirty-two grains) and their kelyphites, in addition to ShP (five garnets and their rims), at Virginia Tech (Blacksburg, VA, USA), Laser Ablation ICPMS Lab (operator: Luca Fedele), using an Agilent 7500 ce inductively coupled plasma-mass spectrometer (ICP-MS) (Agilent Technologies, Santa Clara, CA, USA) combined with an 
Excimer 193 nm GeoLasPro Laser Ablation (LA) system with He gas flow (Coherent, Santa Clara, CA, USA). NIST 610 glass was used as an external standard, and $\mathrm{Cr}$ or Fe as internal standard. The analytical precision of measurements of the external NIST 610 glass standard for all elements has been determined to be 2-5\% [39].

In addition to the abbreviated rock names mentioned above, the following abbreviations were used in this study according to [40]:

Alm-almandine $\left(\mathrm{Mg}_{3} \mathrm{Fe}_{2} \mathrm{Si}_{3} \mathrm{O}_{12}\right)$, Amp-amphibole (group), Ap-apatite $\left(\mathrm{Ca}_{5}\left(\mathrm{PO}_{4}\right)_{3}\right.$ $(\mathrm{F}, \mathrm{Cl}, \mathrm{OH})$, Brt—barite $\left(\mathrm{BaSO}_{4}\right), \mathrm{Bt}$ - biotite $\left(\mathrm{K}(\mathrm{Mg}, \mathrm{Fe})_{3} \mathrm{AlSi}_{3} \mathrm{O}_{10}(\mathrm{OH})_{2}\right)$, Cal—calcite $\left(\mathrm{CaCO}_{3}\right)$, $\mathrm{Cb}$-carbonate mineral (group), $\mathrm{Ccp}$-chalcopyrite $\left(\mathrm{CuFeS}_{2}\right), \mathrm{Chl}-$ chlorite $\left((\mathrm{Mg}, \mathrm{Al}, \mathrm{Fe})_{6}\right.$ $\left.\left((\mathrm{Si}, \mathrm{Al})_{4} \mathrm{O}_{10}\right)(\mathrm{OH})_{8}\right), \mathrm{Chr}$-chromite $\left((\mathrm{Mg}, \mathrm{Fe}) \mathrm{Cr}_{2} \mathrm{O}_{4}\right), \mathrm{Clt}$-celestine $\left(\mathrm{SrSO}_{4}\right), \mathrm{Cpx}$-clinopyroxene $\left(\mathrm{Ca}(\mathrm{Mg}, \mathrm{Fe}) \mathrm{SiO}_{6}\right), \mathrm{Ep}$ — epidote (group), $\mathrm{Gn}$ —galena (PbS), Grt—garnet (group), Kfs—K-feldspar $\left(\mathrm{KAlSi}_{3} \mathrm{O}_{8}\right), \mathrm{Ky}$ - kyanite $\left(\mathrm{AlSi}_{2} \mathrm{O}_{5}\right)$, Mfr-magnesioferrite $\left(\mathrm{MgFe}_{2} \mathrm{O}_{4}\right)$, Mag-magnetite $\left(\mathrm{Fe}_{3} \mathrm{O}_{4}\right)$, Ms-muscovite $\left(\mathrm{KAl}_{2} \mathrm{AlSi}_{3} \mathrm{O}_{10}(\mathrm{OH})_{2}\right), \mathrm{Ol}$-olivine $\left((\mathrm{Mg}, \mathrm{Fe}) \mathrm{SiO}_{4}\right)$, Opx—orthopyroxene $\left((\mathrm{Mg}, \mathrm{Fe}) \mathrm{SiO}_{3}\right), \mathrm{Phl}$-phlogopite $\left(\mathrm{KMg}_{3} \mathrm{AlSi}_{3} \mathrm{O}_{10}(\mathrm{OH})_{2}\right), \mathrm{Pl}$ - plagioclase $\left((\mathrm{Ca}, \mathrm{Na})(\mathrm{Al}, \mathrm{Si}) \mathrm{AlSi}_{2} \mathrm{O}_{8}\right)$, Pn—pentlandite $\left((\mathrm{Fe}, \mathrm{Ni})_{9} \mathrm{~S}_{8}\right)$, Po-pyrrhotite (FeS), Prp-pyrope $\left(\mathrm{Mg}_{3} \mathrm{Al}_{2} \mathrm{Si}_{3} \mathrm{O}_{12}\right)$, Qz-quartz (SiO2), Scp - scapolite $\left((\mathrm{Na}, \mathrm{Ca})_{4}(\mathrm{Si}, \mathrm{Al})_{12} \mathrm{O}_{24}\left(\mathrm{Cl}_{1}, \mathrm{CO}_{3}, \mathrm{SO}_{4}\right)\right)$, Sp - sphalerite $(\mathrm{ZnS})$, Srp - serpentine $\left((\mathrm{Mg}, \mathrm{Fe})_{6}\left[\mathrm{Si}_{4} \mathrm{O}_{10}\right](\mathrm{OH})_{8}\right)$, Sdl一 sodalite $\left(\mathrm{Na}_{4} \mathrm{Si}_{3} \mathrm{Al}_{3} \mathrm{O}_{12} \mathrm{Cl}\right)$, Spl—spinel $\left((\mathrm{Mg}, \mathrm{Fe}) \mathrm{Al}_{2} \mathrm{O}_{4}\right)$, Ststaurolite $\left(\mathrm{Al}_{4} \mathrm{Fe}\left(\mathrm{Si}_{2} \mathrm{O}_{10}\right)(0 \mathrm{H})_{2}\right)$, Tur-tourmaline $\left(\mathrm{Na}\left(\mathrm{Mg}, \mathrm{Fe}^{2+}, \mathrm{Mn}, \mathrm{Li}, \mathrm{Al}_{,} \mathrm{Fe}^{3+}\right)_{3} \mathrm{Al}_{6}\left\{\left(\mathrm{BO}_{3}\right)_{3}\left[\mathrm{Si}_{6} \mathrm{O}_{18}\right]\right.\right.$ $\left.(\mathrm{OH}, \mathrm{F})_{4}\right)$, Usp-ulvöspinel $\left(\mathrm{Fe}_{2} \mathrm{TiO}_{4}\right)$. The abbreviation of $\mathrm{Dj}$-djerfisherite and Fe-phltetraferriphlogopite were also used. Fe-Ol or Fe-Px-in this study: Olivine or pyroxene with an iron component noticeably higher than that in primary rock-forming minerals with the same name. CMIO-Unnamed Calcium Magnesium Iron Oxide $(\mathrm{Ca}, \mathrm{Mn}) \mathrm{Mg}(\mathrm{Fe}, \mathrm{Al}, \mathrm{Si})_{6} \mathrm{O}_{11}$ (according to [41]).

\section{Results}

\subsection{Classification}

Kelyphite rims on garnets are considered below as separate mineral assemblages (Table 1) with complex relations and phase transformations.

Table 1. Main and accessory minerals in the different types of rims on mantle xenolith garnets.

\begin{tabular}{|c|c|c|c|c|c|c|c|c|c|c|c|c|c|c|c|c|c|}
\hline Rim & $\mathrm{P} / \mathrm{g}$ & $\mathbf{n}$ & Opx & Cpx & Spl & Phl & Amp & Kfs & Pl & Sdl & Chl & Srp & Cal & Mag * & Su & $\mathrm{Fe}^{*}$ & Others \\
\hline \multirow{5}{*}{ rim1 } & MHD & 27 & + & + & + & + & + & + & & + & + & + & & & & & \\
\hline & ShP & 5 & + & + & + & + & + & + & & + & & & & & + & & \\
\hline & Ecl-A & 8 & + & + & + & + & + & & + & + & + & & & & & & \\
\hline & Ecl-B & 5 & + & + & + & + & + & + & + & + & & & & + & + & & + \\
\hline & Ecl-C & 4 & & + & + & & + & & + & & & & & 1 & + & & + \\
\hline \multirow{5}{*}{ rim2 } & MHD & 25 & + & + & + & + & + & + & + & + & + & + & + & + & + & + & + \\
\hline & ShP & 5 & + & + & + & + & + & & & + & & + & + & & + & + & + \\
\hline & Ecl-A & 3 & + & + & + & + & + & + & + & & & & & & & & \\
\hline & Ecl-B & 3 & + & + & + & + & + & + & + & & & & + & & + & + & + \\
\hline & Ecl-C & 1 & & + & + & & & & + & & & & + & & & & + \\
\hline \multirow{2}{*}{ rim3 } & MHD & 5 & & & + & + & & & & & & & inc & + & & & \\
\hline & Ecl-A & 2 & & & & + & & & & & & & inc & + & & & \\
\hline rim4 & MHD & 4 & + & + & + & + & + & + & & + & + & + & & & & & \\
\hline $\operatorname{rim} 5$ & MHD & 3 & + & + & + & + & + & + & & + & & & & & + & & \\
\hline
\end{tabular}

Classification and description of rim1-5 from this work; $\mathrm{n}$-number of samples whose garnet has such a rim type; inc-inclusion; mag *—magnetite, Ti-magnetite, ulvöspinel; Fe *—olivine and phlogopite with increased iron content; others—see text.

The classification of kelyphite types is based on several criteria. An important aspect is the size of the mineral grains of the rim: Tens of microns, the first microns, a finer-sized structure. The chemical composition of minerals matters. The position of the rim is also considered: Between garnet and kimberlite, between garnet and olivine/pyroxene, or between olivine/pyroxene and another rim. As this study shows, all of these factors are interrelated. A schematic representation of the rims locations and compositions is shown in Figure A1 in Appendix A.

\subsubsection{Kelyphite Rims in MHD Samples}

The rims (Figures 2 and A1 and Table 1) showed the greatest textural and compositional variety. They were classified into five types. The first two (rim1 and rim2) are 
structurally, in fact, two parts of the same rim: Rim1 is "fine-grained", adjacent to garnet, and rim2 is "coarse-grained", located closer to olivine/pyroxene. The border between them can be clear (Figure 2d,f) or blurred (Figure 2c,e). The main constituent minerals of these two rims are the same (two pyroxenes, spinel, phlogopite), but the compositions and proportions are different. Sometimes, rim 2 may be missing.
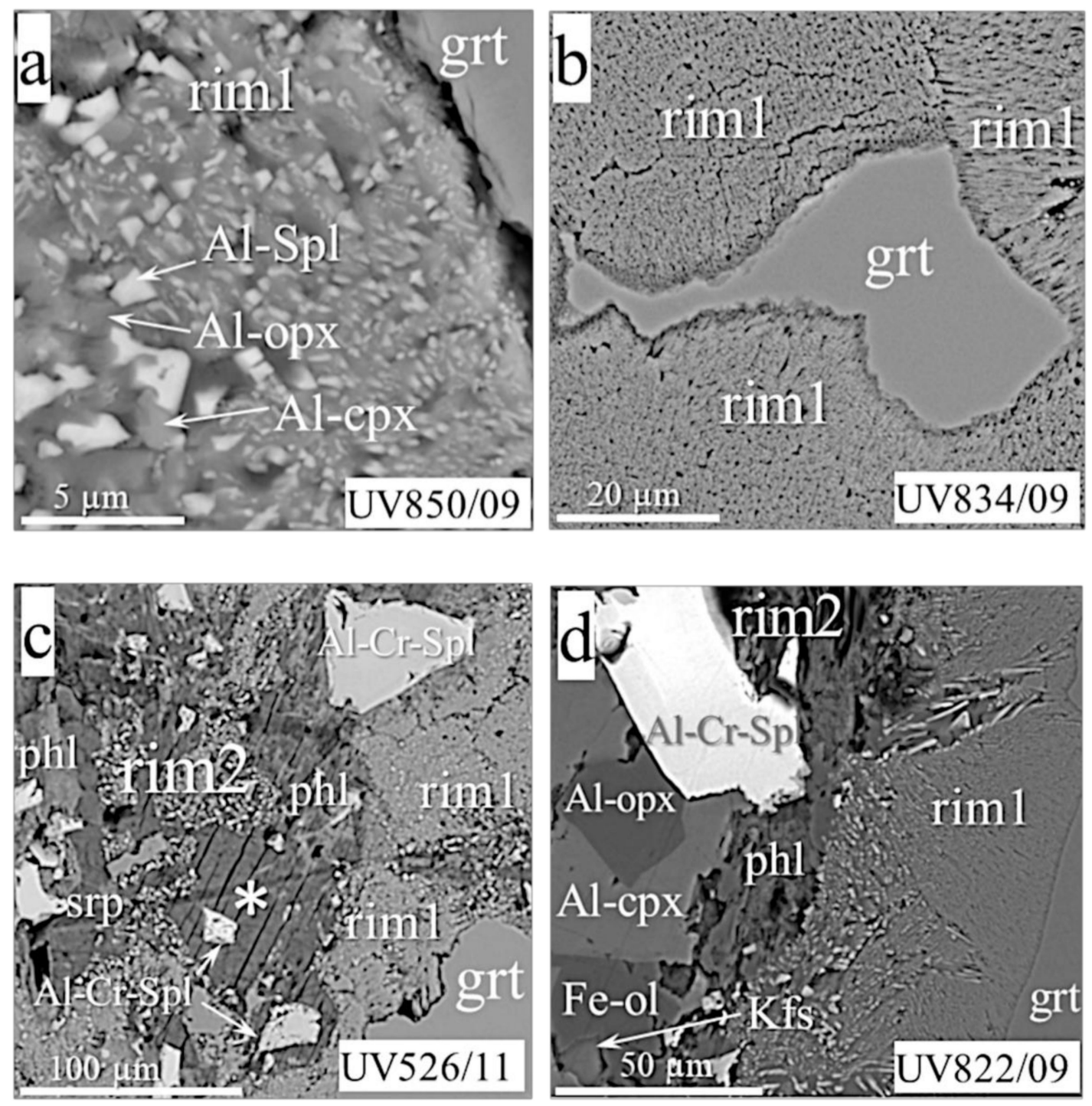

Figure 2. Cont. 

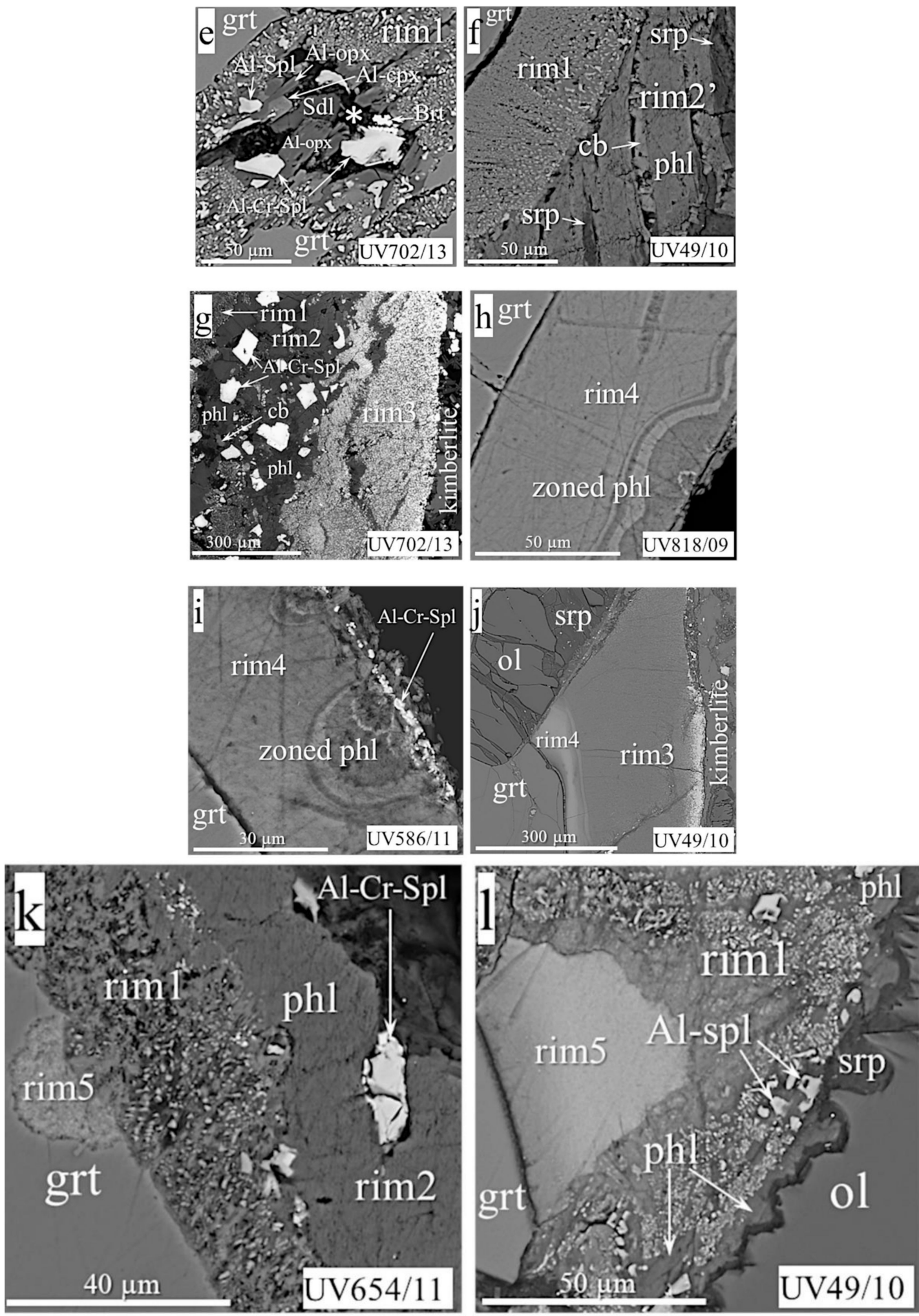

Figure 2. BSE images of the kelyphitic rims on pyropes from MHD: (a) Rim1 with mineral grains gradually increasing in the di-rection from the garnet; (b) garnet grain relict surrounded by rim1 aggregates; (c,d) sharp jump from rim1 to rim2; (e) rim1, developing along cracks in a garnet, with a pronounced rim2 spot; (f) rim1, sharply bordered on unusual rim2 (rim2'), consisting of phlogopite, calcium carbonate, and serpentine; (g) rim3 develops on rim2; (h) rim4 (zoned high chromium phlogopite); (i) rim4 with Cr-spinel grains in outer side; (j) rim3 develops on rim4; (k) rims 1, 2, and 5 (a "pocket" into garnet); (1) rims 1, 2, and 5 (a "pocket" into rim1). Asterisks in (c) and (e) indicate an unidentified hydrous chromium-containing magnesium aluminosilicate with chlorine (see text). 
1. Rim1, from a few to 180 microns thick, is located between garnet and olivine or in garnet cracks (Figure $2 \mathrm{a}-\mathrm{g}, \mathrm{k}, \mathrm{l})$. The rim minerals coarsen gradually or abruptly outward from garnet. The size of mineral grains rarely reaches 15-20 microns and, generally, does not exceed 10 microns. The rim assemblages usually consist of the typical intergrowths of rounded isometric or elongated randomly located grains of orthopyroxene, clinopyroxene, and spinel. Phlogopite, and rarely amphibole, sodalite, feldspar, chlorite, and serpentine, occur interstitially to those minerals. Rims of this type in MHD samples are sometimes equigranular (Figure 2b,k) or look like cones of gradually increasing intergrown grains (Figure $2 \mathrm{a}, \mathrm{d}, \mathrm{f})$, but most often they are patched mixtures with rim2 (Figure 2c,e).

2. Rim2, $\leq 90$ microns thick, occurs as continuous or discontinuous envelopes around rim1 (Figure 2d,f,g), or as patches inside rim1 (Figure 2c,e). The grain size of rim2 is typically tens of microns. The rim often presents hypidiomorphic phlogopite plates with or without enclosed spinel grains (Figure 2f,g,k). Sometimes, it also contains ortho- and clinopyroxene, sodalite, amphibole, feldspar, plagioclase, calcite, serpentine, tetraferriphlogopite, and Fe-olivine (Figure 2d,e,f). In this case, phlogopite, serpentine, tetraferriphlogopite, and sodalite fill the intergranular space of other minerals (Figure 2c,d,e). Fe-Ni sulfides rarely occur as inclusions within serpentine at the periphery of the rim closer to olivine. Djerfisherite with a size of about 5 microns was found in phlogopite near rim1. A layered hydrous magnesium aluminosilicate phase bearing $\mathrm{Cr}$ and $\mathrm{Cl}$ was found in six samples (asterisked in Figure 2c,e). Sometimes, this is represented by large (up to 80 microns) plates, partially replaced by phlogopite, with disseminated spinel grains and local areas of rim1 (Figure 2c). In other samples, it was found in the intergranular space together with barite (Figure 2e). The rim on the UV49/10 garnet (Figure 2f; referred to as rim2' in the Discussion) has an unusual, banded texture, consisting of large phlogopite flakes alternating with calcite lamellae. The intergrowths are located at an angle of $45^{\circ}$ to the border rim $1 /$ rim2'. Rims 1 and 2 surround garnets in most studied samples.

3. Rim3, the phlogopite-spinel-magnetite rim, up to $350 \mu \mathrm{m}$ thick, usually occurs between garnet and kimberlite, and rarely between kimberlite and other types of rim (Figure $2 \mathrm{~g}, \mathrm{j}$ ). It consists mostly of phlogopite with enclosed changing composition spinel grains, and has a zonal structure, with phlogopite percentages higher near garnet and more abundant magnetite near kimberlite. The size of mineral grains varies from fractions of a micron to 7-8 microns at the border with kimberlite.

4. Rim4 is zoned, up to 100 microns thick, composed of cryptocrystalline high-Cr phlogopite/hydrophlogopite; rare Cr-spinel grains with a size of about one micron are sometimes located on the outer band of the rim (Figure 2i). Such rims are found in samples UV586/11 and UV818/89, instead of rim1 and rim2 (Figure 2h,i). Rim4 is partially replaced by rim3 in samples UV159/10-2 and UV49/10 (Figure 2j).

5. Rim5 comprises "pockets" found between garnet and rim1 (Figure 2k,l) in three samples. They have a hemispherical (or close to) shape with a radius of 10 to 50 microns and an uneven spotty structure in the BSE mode.

\subsubsection{Kelyphite Rims in ShP Samples}

Rims 1 and 2 are similar to those in MHD in texture and distribution of minerals (Table 1, Figures 3 and A1a), but more often contain amphibole and can be located not only between garnet and olivine, but also between garnet and orthopyroxene (Figure 3d). 

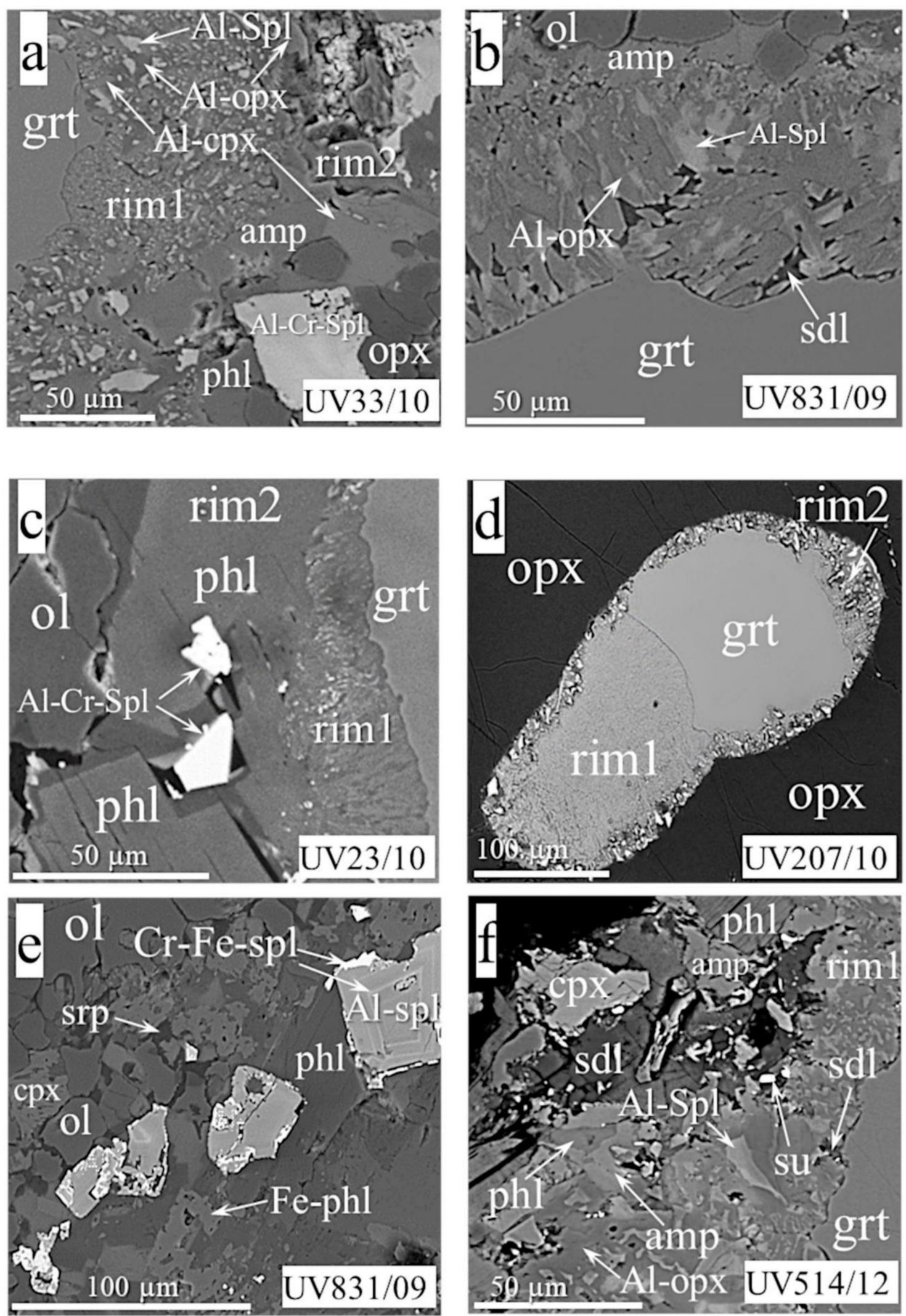

Figure 3. BSE images of the kelyphitic rims on pyropes from ShP: (a) Rim1, bordered by rim2, which is represented by large grains of pyroxenes, spinel, phlogopite, and amphibole; (b) unusually "coarse-grain" rim1; (c) rim1 bordered by phlogopite with rare Al-Cr spinel grains (rim2); (d) garnet grains in orthopyroxene with pronounced rims 1 and 2; (e) rim2, folded by zonal phlogopite and spinel, is the outer part of the rim1 shown in (b); (f) rims 1 and 2 without a clear boundary between them. 
1. Rim1 (Figure 3a-d,f) comprises intergrowths of spinel, orthopyroxene, clinopyroxene, phlogopite, amphibole, sodalite, and K-Na-feldspar in various combinations, or, more rarely, are all present in one rim. Phlogopite, sodalite, and feldspar usually occur interstitially (Figure 3b,f). Fe-olivine was found as xenomorphic grains located around Al-spinel in the rim of sample UV831/09. This rim at the contact with garnet is more similar texturally to rim 2 than to rim1 (Figure 3b), with coarser grains (tens of microns) of Al-pyroxenes and spinel. Fe-Ni-sulfides and djerfisherite in the form of individual grains or inter-growths were in the space between the main minerals in the outer part of the rim on the border with recrystallized olivine of the ground mass.

2. Rim2 (Figure $3 \mathrm{a}, \mathrm{c}, \mathrm{e}, \mathrm{f}$ ) contains the same minerals as rim1 (two pyroxenes and spinel) but with coarser grain sizes. The mineral assemblage also includes phlogopite as hypidiomorphic plates (Figure 3c) and a lower abundance of amphibole (Figure 3a,f), feldspar, sodalite (Figure 3f), calcite, and serpentine (Figure 3e). Intergrowths of Feolivine and Al-pyroxenes surround zoned crystals of Al-spinel in rim2, which develops within the crack in one of the garnets of sample UV831/09. Baritocelestite (with different proportions of barite and celestine components) fills cracks and cavities in Al-spinel of sample UV33/10. Rim2 of sample UV831/09 consists of intergrown phlogopite of variable Al-Fe compositions (phlogopite and tetraferriphlogopite) and aluminous spinel with distinct zones of $\mathrm{Cr}$-Fe spinel (appearing as light-color bands in a gray spinel crystal in Figure 3e). In the same rim, Ni sulfide (sometimes with a djerfisherite edging) was noted in the form of inclusions in spinel or phlogopite at the outer border of the rim.

3. Rim3 is identical in appearance to the corresponding rim on MHD garnets. Apparently, the mineral association is the same.

\subsubsection{Kelyphite Rims in A, B, C Ecl Samples}

The rims were analyzed in eight samples of group $\mathrm{A}$, five samples of group $\mathrm{B}$, and four samples of group C (Table 1, Figures 4 and A1a). Kyanite eclogite UV66/09 contains garnets of two Ecl groups (A and C) in the different parts of the sample (Figure 4i). Both garnets have kelyphite rims (Figure 4c,j). Therefore, Ecl UV66/09 is considered to be two samples: UV66/09-A and UV66/09-C.
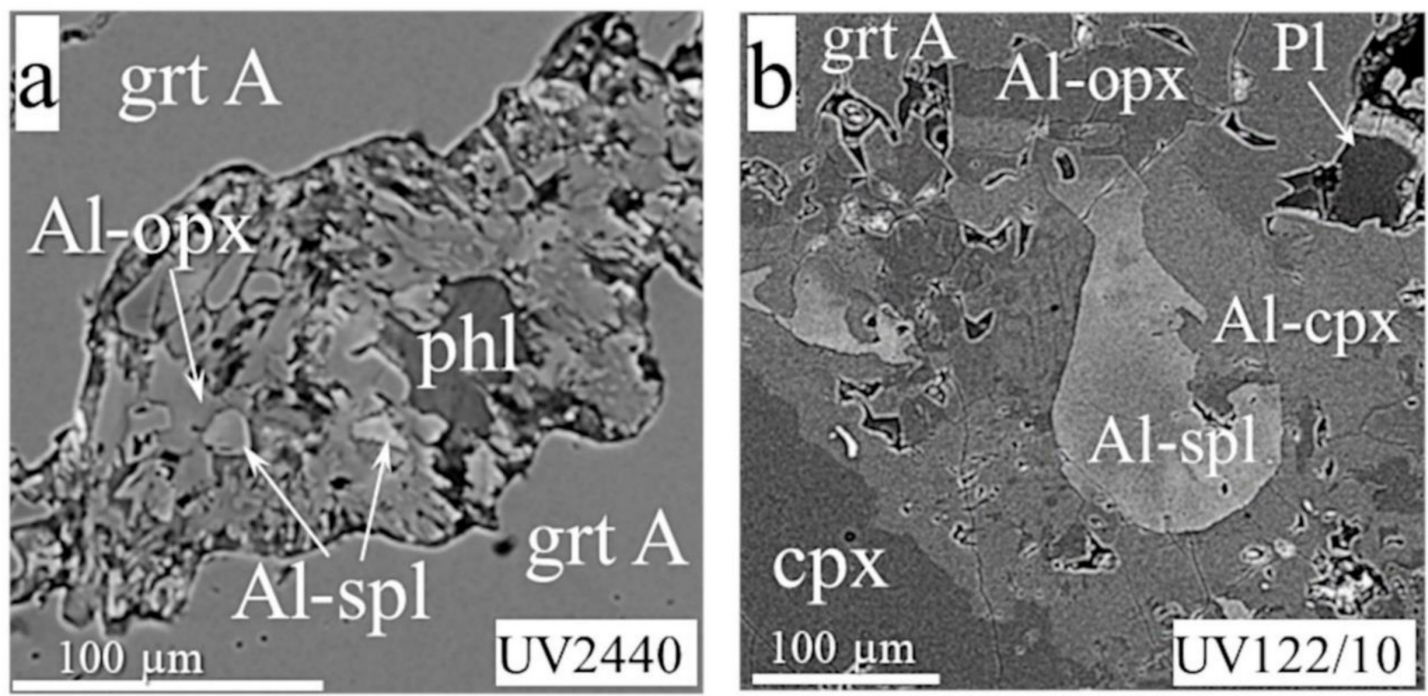

Figure 4. Cont. 

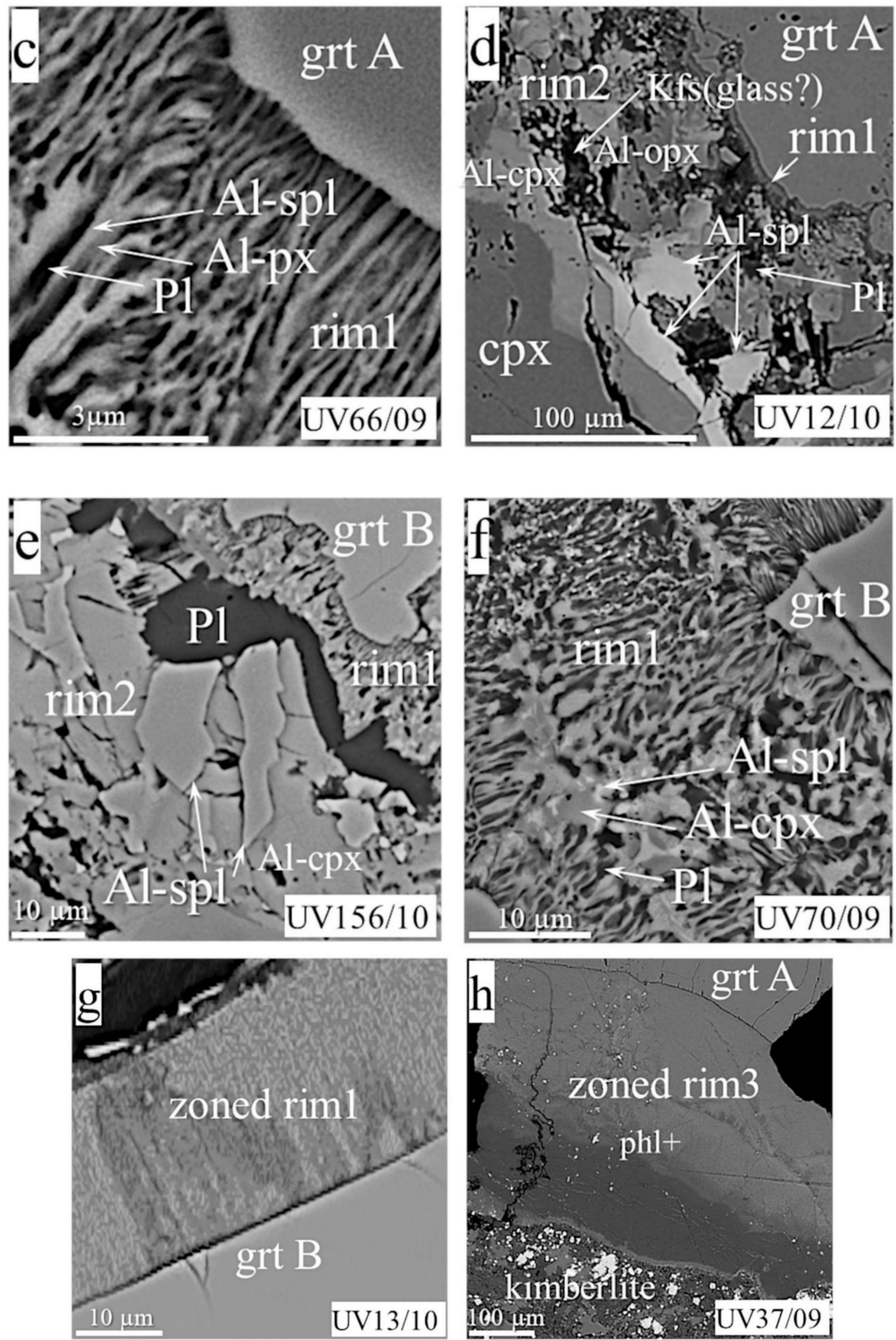

Figure 4. Cont. 

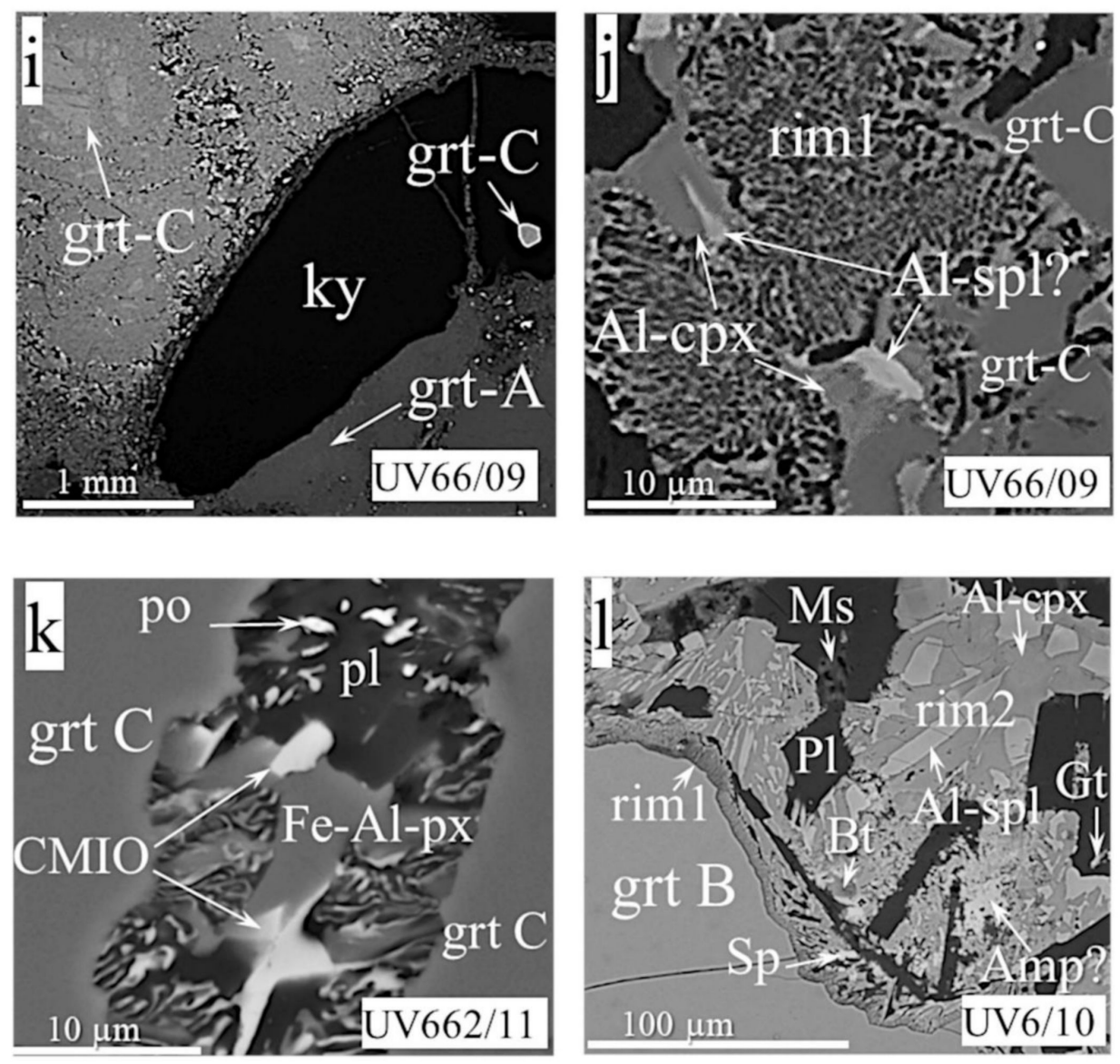

Figure 4. BSE images of the kelyphitic rims on garnets from Ecl A, B, C: (a) Rim1 developing in a crack of Ecl A garnet from di-amondiferous eclogite; (b) enlarged rim2 minerals; (c) strongly elongated symplectites of rim1 on Ecl A garnet; (d) rim1 (narrow strip of symplectites surrounding the garnet) and rim2 (large grains of Al-opx, Al-cpx, Al-spl); (e) rim1 on Ecl B garnet, separated from rim 2 by a strip of plagioclase; (f) symplectites of the rim1 surrounding several grains of Ecl B garnet; (g) very thin symplectites of zoned rim1 on the Ecl B garnet; (h) zoned rim3 on Ecl A garnet; (i) Ecl A and C garnets in kyanite eclogite UV66/09; (j) rim1 surrounding several grains of Ecl C garnet; (k) rim1 in a crack of group C garnet; (1) rim1 (narrow strip around the group $\mathrm{C}$ garnet) and complex unstructured rim2.

1. Rim1, 10-15 $\mu \mathrm{m}$ (Figure 4c-f,k) thick, rarely more (Figure 4g,l), with prominent symplectite structures of vermicular or elongated grains perpendicular to the "garnet-rim" boundary (Figure 4c,e-g). The rim mineralogy differs in different groups, but aluminous spinel is present in almost all rim assemblages (Table 1). Additionally, typical rim phases in Ecl A are clinopyroxene and orthopyroxene, sometimes amphibole instead of or after pyroxene. Phlogopite, sodalite, and plagioclase occur interstitially. Chlorite is the product of their replacement. Ecl B have rims with slightly different relative percentages of phases and high Fe content in the lat. The mineralogy consists of Al-Fe-pyroxenes/amphibole and Al-spinel symplectites, interstitial phlogopite, plagioclase, K-feldspar, or sodalite, and phases stoichiometrically corresponding to tourmaline and staurolite (sample UV156/10). Magnetite and Fe-Ni-Cu sulfides occur on this type of rim periphery as individual interstitial grains (samples UV211/10, UV13/10, UV139/09). The rim in Ecl C lacks orthopyroxene and phlogopite and consists of AlFe-clinopyroxene, plagioclase, spinel, and rare amphibole. The garnet rim in sample UV662/11, instead of spinel, contains OCMI (see Abbreviations) intergrowth with the pyroxene (Figure 4k). Pyrrhotite enclosed within the plagioclase was found in that rim. The rim on the garnet of diamond-bearing Ecl A (sample UV2440) looks like this on garnet of ShP sample UV831/09, described above (Figures $4 a$ and $3 b$, respectively). 
Rim1 in the Ecl B sample UV13/10 is broader than this in other Ecl. Dark and light areas (in BSE mode) attest to the unequal distribution of minerals in the rim (Figure $4 \mathrm{~g}$ ).

2. Rim2 was found in three samples of Ecl A, three samples of Ecl B, and one sample of Ecl C (Figure $4 b, d, e, l)$. Practically all of these rims contain Al-spinel, Al-Fe-clinopyroxene, and plagioclase, which is either intergrown with two other minerals or occurs as a band between rim1 and rim2 (Figure 4e,l). Rim2 in sample UV13/10 contains the spots of the rim1 symplectites. Al-orthopyroxene or Fe-olivine rarely occur together or instead of Al-clinopyroxene in the rim of Ecl A and B (Figure 4b,d). Feldspar, plagioclase, amphibole, phlogopite, and calcite usually fill the intergranular space (Figure $4 b, d$ ). Additionally, pyrite, pyrrhotite, and djerfisherite, which surrounds it as a ragged strip, are present as inclusions in feldspar in rim2 of Ecl A and B (e.g., sample UV139/09). A phase stoichiometrically similar to Fe-amphibole appears in the rim of sample UV6/10, which also contains biotite and muscovite in different parts, in addition to a few grains of sphalerite (wurtzite) and galena (Figure 41). The rim of sample UV66/09-C bears interstitial calcite and a phase identified as scapolite.

3. Rim3, 450 microns thick, between garnet and kimberlite in Ecl A (Figure 4h), looks like the respective rim in MHD samples. Rims of this type comprise three visible zones of light, dark, and exceptionally light colors (outward from garnet); the latter is a very thin band that contours the rim at the boundary with kimberlite. All zones consist of compositionally variable phlogopite and spinels occurring as inclusions in cracks.

\subsection{Analytical Data}

\subsubsection{Chemistry of Main Rim Minerals}

The results of analyses of the kelyphitic rim's main minerals' chemical composition and the compositions of the primary (rock-forming) minerals with the same name are given in Table 2.

Table 2. Chemical compositions of primary (rock-forming) minerals of MHD, ShP, and Ecl mantle xenoliths and the same-named minerals and phlogopite in the different types of kelyphitic rims.

\begin{tabular}{|c|c|c|c|c|c|c|c|c|c|c|c|c|c|c|c|c|}
\hline $\mathbf{P}$ & $\mathbf{L}$ & $\mathbf{M} / \mathbf{n}$ & $\mathrm{SiO}_{2}$ & $\mathrm{TiO}_{2}$ & $\mathrm{Al}_{2} \mathrm{O}_{3}$ & $\mathrm{Cr}_{2} \mathrm{O}_{3}$ & $\mathrm{FeO}$ & $\mathrm{MnO}$ & $\mathrm{MgO}$ & $\mathrm{CaO}$ & $\mathrm{Na}_{2} \mathrm{O}$ & $\mathrm{K}_{2} \mathrm{O}$ & Total & $\mathrm{Mg}$ \# & $\mathrm{Cr} \#$ & Ts \\
\hline \multirow{17}{*}{ MHD } & \multirow{2}{*}{ rock } & $\mathrm{opx} / 2$ & 58.5 & 0.01 & 0.41 & 0.32 & 4.39 & 0.06 & 36.1 & 0.07 & 0.09 & 0.00 & 100 & 0.94 & 0.34 & 0.01 \\
\hline & & $\mathrm{spl} / 8$ & 0.00 & 0.34 & 7.00 & 61.2 & 19.6 & 0.23 & 11.5 & 0.00 & 0.00 & 0.00 & 99.8 & 0.57 & 0.85 & n.c. \\
\hline & \multirow{4}{*}{ rim1 } & opx/39 & 49.3 & 0.05 & 8.19 & 4.21 & 7.05 & 0.45 & 28.7 & 1.75 & 0.12 & 0.09 & 99.9 & 0.88 & 0.26 & 0.28 \\
\hline & & cpx/44 & 49.4 & 0.24 & 8.00 & 3.67 & 3.97 & 0.40 & 16.0 & 16.8 & 1.24 & 0.14 & 100 & 0.88 & 0.24 & 0.11 \\
\hline & & $\mathrm{spl} / 16$ & n.d. & 0.52 & 34.0 & 31.1 & 16.0 & 0.63 & 16.5 & 0.05 & n.d. & n.d. & 98.8 & 0.71 & 0.38 & n.c. \\
\hline & & $\mathrm{phl} / 11$ & 41.1 & 0.38 & 10.9 & 2.16 & 4.73 & 0.05 & 24.2 & 0.49 & 0.37 & 9.09 & 93.5 & 0.90 & 0.12 & n.c. \\
\hline & \multirow{4}{*}{$\operatorname{rim} 2$} & opx/42 & 53.5 & 0.05 & 5.13 & 2.17 & 6.15 & 0.38 & 30.6 & 1.62 & 0.18 & 0.05 & 99.8 & 0.90 & 0.22 & 0.16 \\
\hline & & $\mathrm{cpx} / 35$ & 52.7 & 0.26 & 4.86 & 2.45 & 3.62 & 0.35 & 16.8 & 17.4 & 1.49 & 0.02 & 100 & 0.89 & 0.25 & 0.10 \\
\hline & & $\mathrm{spl} / 48$ & n.d. & 1.88 & 22.8 & 39.4 & 20.6 & 0.37 & 14.3 & 0.26 & n.d. & n.d. & 99.4 & 0.64 & 0.54 & n.c. \\
\hline & & $\mathrm{phl} / 45$ & 40.4 & 1.02 & 12.8 & 2.17 & 4.20 & 0.04 & 23.4 & 0.22 & 0.36 & 9.36 & 93.9 & 0.91 & 0.10 & n.c. \\
\hline & \multirow{4}{*}{$\operatorname{rim} 3$} & $\mathrm{spl} / 29$ & 0.09 & 12.7 & 5.36 & 8.01 & 54.7 & 2.23 & 12.6 & 0.09 & 0.00 & 0.00 & 95.8 & 0.59 & 0.53 & n.c. \\
\hline & & $\mathrm{phl} / 21$ & 37.0 & 0.89 & 13.7 & 3.69 & 5.25 & 0.10 & 22.9 & 0.18 & 0.09 & 9.51 & 93.2 & 0.89 & 0.11 & n.c. \\
\hline & & & 37.0 & 0.55 & 15.1 & 4.86 & 5.85 & 0.23 & 21.9 & 0.00 & 0.00 & 10.0 & 95.5 & 0.87 & 0.18 & n.c. \\
\hline & & $\mathrm{p}-\mathrm{k}$ & 40.4 & 0.00 & 8.73 & 0.00 & 3.73 & 0.00 & 27.4 & 0.00 & 0.00 & 9.5 & 96.3 & 0.93 & 0.00 & n.c. \\
\hline & \multirow{3}{*}{$\operatorname{rim} 4$} & phl/11 & 33.2 & 0.47 & 11.2 & 10.3 & 6.05 & 0.44 & 21.1 & 0.06 & 0.04 & 8.29 & 91.1 & 0.64 & 0.00 & n.c. \\
\hline & & $\mathrm{Cr}_{\min }$ & 37.0 & 0.37 & 12.0 & 6.36 & 3.42 & 0.00 & 23.0 & 0.00 & 0.00 & 9.14 & 91.3 & 0.92 & 0.26 & n.c. \\
\hline & & $\mathrm{Cr}_{\max }$ & 32.2 & 0.52 & 11.6 & 11.9 & 5.36 & 0.45 & 20.2 & 0.00 & 0.00 & 7.95 & 90.4 & 0.87 & 0.41 & n.c. \\
\hline
\end{tabular}


Table 2. Cont.

\begin{tabular}{|c|c|c|c|c|c|c|c|c|c|c|c|c|c|c|c|c|}
\hline $\mathbf{P}$ & $\mathbf{L}$ & $\mathbf{M} / \mathbf{n}$ & $\mathrm{SiO}_{2}$ & $\mathrm{TiO}_{2}$ & $\mathrm{Al}_{2} \mathrm{O}_{3}$ & $\mathrm{Cr}_{2} \mathrm{O}_{3}$ & $\mathrm{FeO}$ & $\mathrm{MnO}$ & $\mathrm{MgO}$ & $\mathrm{CaO}$ & $\mathrm{Na}_{2} \mathrm{O}$ & $\mathrm{K}_{2} \mathrm{O}$ & Total & Mg \# & $\mathrm{Cr} \#$ & Ts \\
\hline \multirow{10}{*}{ ShP } & \multirow[b]{2}{*}{ rock } & opx $/ 5$ & 58.6 & 0.00 & 0.70 & 0.27 & 5.53 & 0.00 & 34.6 & 1.03 & 0.25 & 0.03 & 101 & 0.92 & 0.21 & 0.02 \\
\hline & & $\mathrm{cpx} / 4$ & 54.5 & 0.40 & 2.38 & 0.92 & 3.42 & 0.00 & 18.3 & 18.9 & 1.25 & 0.00 & 99.9 & 0.90 & 0.21 & 0.01 \\
\hline & \multirow{4}{*}{ rim1 } & opx $/ 7$ & 48.3 & 0.45 & 10.8 & 2.82 & 7.82 & 0.35 & 27.6 & 1.89 & 0.00 & 0.00 & 100 & 0.86 & 0.15 & 0.30 \\
\hline & & $\mathrm{cpx} / 7$ & 46.5 & 1.26 & 11.3 & 3.05 & 4.78 & 0.18 & 14.8 & 16.9 & 0.65 & 0.06 & 99.5 & 0.85 & 0.15 & 0.16 \\
\hline & & $\mathrm{spl} / 28$ & n.d. & 0.55 & 44.2 & 20.6 & 14.13 & 0.09 & 18.4 & 0.01 & n.d. & n.d. & 97.9 & 0.76 & 0.24 & n.c. \\
\hline & & $\mathrm{phl} / 6$ & 40.5 & 1.73 & 13.7 & 2.05 & 3.39 & 0.00 & 23.2 & 0.07 & 0.39 & 9.8 & 94.9 & 0.92 & 0.09 & n.c. \\
\hline & \multirow{4}{*}{$\operatorname{rim} 2$} & opx/4 & 52.1 & 0.13 & 5.59 & 1.95 & 6.74 & 0.49 & 30.2 & 1.55 & 0.00 & 0.00 & 98.8 & 0.89 & 0.19 & 0.18 \\
\hline & & $\mathrm{cpx} / 4$ & 49.5 & 1.16 & 7.15 & 1.87 & 3.93 & 0.16 & 15.3 & 19.1 & 1.09 & 0.00 & 99.2 & 0.87 & 0.15 & 0.11 \\
\hline & & $\mathrm{spl} / 24$ & n.d. & 2.10 & 23.8 & 38.7 & 19.7 & 0.13 & 15.0 & 0.04 & n.d. & n.d. & 99.4 & 0.67 & 0.53 & n.c. \\
\hline & & $\mathrm{phl} / 9$ & 40.0 & 2.15 & 14.6 & 2.09 & 3.81 & 0.00 & 22.6 & 0.08 & 0.53 & 9.35 & 95.3 & 0.91 & 0.09 & n.c. \\
\hline Ecl A & \multirow{3}{*}{ rock } & срх /19 & 55.0 & 0.21 & 3.03 & 0.16 & 4.16 & 0.08 & 15.5 & 19.2 & 2.40 & 0.03 & 99.8 & 0.87 & 0.03 & 0.00 \\
\hline Ecl B & & $\mathrm{cpx} / 20$ & 55.1 & 0.41 & 7.64 & 0.06 & 4.59 & 0.05 & 11.7 & 15.3 & 4.92 & 0.12 & 99.9 & 0.82 & 0.01 & 0.01 \\
\hline $\mathrm{Ecl} \mathrm{C}$ & & срx/7 & 56.1 & 0.30 & 14.0 & 0.06 & 2.99 & 0.02 & 7.20 & 11.6 & 7.67 & 0.03 & 100 & 0.81 & 0.00 & 0.01 \\
\hline \multirow{11}{*}{ EclA, B } & \multirow{4}{*}{ rim1 } & opx/12 & 48.7 & 0.45 & 9.75 & 0.11 & 14.2 & 0.45 & 24.4 & 1.68 & 0.02 & 0.01 & 99.8 & 0.75 & 0.01 & 0.25 \\
\hline & & $\mathrm{cpx} / 15$ & 46.7 & 0.84 & 11.0 & 0.10 & 9.74 & 0.34 & 12.6 & 18 & 0.67 & 0.04 & 100 & 0.7 & 0.01 & 0.24 \\
\hline & & $\mathrm{spl} / 16$ & n.d. & 0.22 & 58.4 & 0.19 & 23.1 & 0.14 & 15.3 & 0.33 & n.d. & n.d. & 97.7 & 0.61 & 0.00 & n.c. \\
\hline & & $\mathrm{phl} / 13$ & 37.5 & 0.7 & 17.6 & 0.02 & 14.0 & 0.38 & 14.2 & 0.54 & 0.45 & 8.14 & 93.5 & 0.64 & 0.00 & n.c. \\
\hline & \multirow{4}{*}{$\operatorname{rim} 2$} & opx/2 & 52.0 & 0.15 & 6.41 & 0.00 & 12.0 & 0.53 & 27.4 & 1.61 & 0.00 & 0.00 & 100 & 0.8 & 0.00 & 0.18 \\
\hline & & $\mathrm{cpx} / 12$ & 48.4 & 0.61 & 7.95 & 0.17 & 10.3 & 0.45 & 13.9 & 17.0 & 0.72 & 0.00 & 99.4 & 0.71 & 0.01 & 0.18 \\
\hline & & $\mathrm{spl} / 27$ & n.d. & 0.32 & 55.7 & 0.40 & 26.3 & 0.24 & 13.9 & 0.4 & n.d. & n.d. & 97.4 & 0.57 & 0.01 & n.c. \\
\hline & & $\mathrm{phl} / 4$ & 37.8 & 2.1 & 15.3 & 0.55 & 7.48 & 0.00 & 20.4 & 0.00 & 0.55 & 9.21 & 93.3 & 0.83 & 0.02 & n.c. \\
\hline & \multirow{3}{*}{ rim3 } & $\mathrm{phl} / 10$ & 39.3 & 0.54 & 12.8 & 0.18 & 5.83 & 0.08 & 23.4 & 3.39 & 0.16 & 8.83 & 94.5 & 0.87 & 0.01 & n.c. \\
\hline & & $p-g$ & 37.7 & 0.62 & 11.5 & 0.00 & 9.13 & 0.45 & 19.1 & 7.58 & 0.26 & 7.28 & 94.2 & 0.79 & 0.00 & n.c. \\
\hline & & $\mathrm{p}-\mathrm{k}$ & 37.5 & 0.00 & 15.9 & 0.00 & 2.86 & 0.00 & 25.6 & 0.00 & 0.00 & 8.73 & 94.3 & 0.94 & 0.00 & n.c. \\
\hline \multirow{4}{*}{$\mathrm{Ecl} \mathrm{C}$} & \multirow{2}{*}{$\operatorname{rim} 1$} & cpx/7 & 44.9 & 0.68 & 11.4 & 0.00 & 14.5 & 0.45 & 8.52 & 18.8 & 0.49 & 0.03 & 99.7 & 0.51 & 0.00 & 0.26 \\
\hline & & $\mathrm{spl} / 2$ & n.d. & 0.48 & 54.2 & 0.21 & 36.1 & 0.14 & 8.04 & 0.14 & n.d. & n.d. & 99.2 & 0.34 & 0.00 & n.c. \\
\hline & \multirow{2}{*}{ rim2 } & срх /1 & 46.8 & 0.33 & 7.78 & 0.00 & 14.7 & 0.21 & 10.2 & 18.7 & 0.00 & 0.00 & 98.8 & 0.55 & 0.00 & 0.19 \\
\hline & & $\mathrm{spl} / 2$ & n.d. & 0.71 & 47.3 & 0.15 & 44.0 & 0.37 & 5.31 & 0.10 & n.d. & n.d. & 97.9 & 0.24 & 0.00 & n.c. \\
\hline
\end{tabular}

$\mathrm{P}$-paragenesis; L-location; $\mathrm{M} / \mathrm{n}$-mineral/number of analyses for which the average value is calculated; $\mathrm{Mg} \#=\mathrm{Mg} /\left(\mathrm{Mg}+\mathrm{Fe}{ }^{2+}\right)$, $\mathrm{Cr} \#=\mathrm{Cr} /(\mathrm{Cr}+\mathrm{Al}) ; \mathrm{Ts}$-Tschermak pyroxene component $\mathrm{MgAl}^{\mathrm{VI}} \mathrm{Al}^{\mathrm{IV}} \mathrm{SiO}_{6} ;$ n.d.—not determined, n.c.—not calculated; p-g-phlogopite near the garnet, $\mathrm{p}-\mathrm{k}$ - phlogopite near the kimberlite (zoned rim3); $\mathrm{Cr}_{\min }, \mathrm{Cr}_{\max }$ - phlogopite with minimum and maximum $\mathrm{Cr}_{2} \mathrm{O}_{3}$ (zoned rim4).

Numerous accessory and secondary minerals of the kelyphite rims were not analyzed; this is a topic for a separate study. For the same reason, no data are provided for the frequently occurring amphibole. Here, the attention is directed to the comparison of the chemistry of rock-forming pyroxenes and spinel in the studied parageneses with the kelyphite rim minerals with the same names. Phlogopite also occupies an important place and is present in almost all types of rims of the studied xenoliths.

1. Rim1. The difference in the composition of the same-named rim minerals of peridotite parageneses (MHD and ShP) is due to the paragenetic features of the garnet composition. Although having similar contents of the main components, orthopyroxenes in MHD and ShP rims1 show different $\mathrm{Cr}_{2} \mathrm{O}_{3}$ (and, respectively, $\mathrm{Al}_{2} \mathrm{O}_{3}$ ) (Table 2). The minerals of eclogite rims show much higher iron content and an almost complete absence of chromium. $\mathrm{Al}_{2} \mathrm{O}_{3}$ participates in the formation of the Mg-Tschermak component $\left(\mathrm{MgAl}^{\mathrm{VI}} \mathrm{Al}^{\mathrm{IV}} \mathrm{SiO}_{6}\right)$ in both orthopyroxene and clinopyroxene (although the latter normally contains the Ca-Tschermak component $\left.\left(\mathrm{CaAl}^{\mathrm{VI}} \mathrm{Al}^{\mathrm{IV}} \mathrm{SiO}_{6}\right)\right)$. This is a general trend for the three studied parageneses. Both pyroxenes are present in this rim type in peridotites and eclogites, whereas as rock-forming ones, they are simultaneously present only in the ShP. MHD contain only orthopyroxene (in harzburgites), whereas Ecl contain only clinopyroxene. Moreover, the rock-forming clinopyroxene of $\mathrm{Ecl} \mathrm{C}$ has more $\mathrm{Al}_{2} \mathrm{O}_{3}$ than clinopyroxene in the rim (Table 2), but practically does not contain a Tschermak component, because all aluminum is bound with sodium to form a Jadeite component. Both pyroxenes in the rims of three studied parageneses show notably lower $\mathrm{Mg}$ \# values in comparison with those of primary pyroxenes. $\mathrm{The} \mathrm{Cr}_{2} \mathrm{O}_{3}$ content in the spinel of this type of rim varies from $31 \mathrm{wt} . \%$ in MHD up to $0.2 \mathrm{wt} . \%$ in $\mathrm{Ecl}$ (Table 2). In addition, spinel of the rim contains less $\mathrm{Cr}$ and slightly more Fe than the primary Cr-spinel present in some MHD. The phlogopite compositions of the peridotite parageneses rims are similar, except for the enrichment of phlogopite in the $\mathrm{ShP}$ with titanium $\left(\mathrm{TiO}_{2} 1.73 \mathrm{wt} . \%\right.$, Table 2$)$. The phlogopite composition of the Ecl 
rim differs from that of MHD and ShP in the absence of $\mathrm{Cr}_{2} \mathrm{O}_{3}$ (about $2 \mathrm{wt} . \%$ in the phlogopite of the peridotite garnets rims) and a 3-4-fold excess of $\mathrm{FeO}$ (Table 2). Kelyphites in twenty studied MHD garnets contained Al-clinopyroxene, whose presence generally correlates with $\mathrm{CaO}$ content in garnet (according to this study, the threshold $\mathrm{CaO}$ content in garnet is approximately $1.6 \mathrm{wt} . \%)$. However, this is not always the case. For instance, the rim of megacrystalline harzburgite pyrope with $5.49 \mathrm{wt} . \% \mathrm{CaO}$ (sample UV162/10-1) consists of phlogopite and spinel, whereas rim1 of the same paragenesis pyrope with $6.96 \mathrm{wt} . \% \mathrm{CaO}$ (sample UV654/11) contains amphibole, in addition to phlogopite and spinel, instead of pyroxenes. Some MHD rims are nearly identical to garnets in terms of the bulk composition of the main components (samples UV12/01-1, UV26/10-1, UV667/11); others have slight differences, which are expressed as a lower $\mathrm{SiO}_{2}$ content (by 1.6-6.46 wt.\%) at a higher $\mathrm{MgO}$ content (by $0.9-1.81 \mathrm{wt} . \%$ ), and in the presence of certain amounts of $\mathrm{K}_{2} \mathrm{O}$ (up to $1.85 \mathrm{wt} . \%$ ) and $\mathrm{Na}_{2} \mathrm{O}$ (up to 0.82 wt.\%) (Table 3, MHD). The rims also often have a lower sum (the difference is up to $2.7 \mathrm{wt} . \%$ ) than in garnet. This is most likely due to the presence of a hydrous phase in these rims. The prevalence of $\mathrm{K}_{2} \mathrm{O}$ over $\mathrm{Na}_{2} \mathrm{O}$ indicates the priority presence of phlogopite and potassium feldspar in these rims. Amphibole, sodalite, and plagioclase are found in smaller quantities. In addition, sometimes a deficiency of $\mathrm{CaO}$ (up to $1 \mathrm{wt} . \%$ ), and an excess of chromium (up to $1.62 \mathrm{wt} . \%$ ) and iron (up to $1.1 \mathrm{wt} . \%$ ), in relation to the composition of the MHD garnet can be found in the rims. This can be caused by focusing the central part of the analyzer on spinels. The bulk composition of the rims of the ShP garnets, analyzed in three samples, in general, has more pronounced components differences from the composition of garnet (Table 3, ShP). The excess in $\mathrm{MgO}$ in the rim reaches $2.54 \mathrm{wt} . \%$, and the deficit of $\mathrm{Al}_{2} \mathrm{O}_{3}$, which is almost invisible in the MHD rims, ranges from 1.72 to $2.55 \mathrm{wt} \%$. The amounts of $\mathrm{K}_{2} \mathrm{O}$ and $\mathrm{Na}_{2} \mathrm{O}$ in the rim are close: Up to 1.37 and $1.8 \mathrm{wt} \%$, respectively, which indicates a noticeable role of Na-containing phases, in addition to K-containing ones. The rim1 bulk composition of the Ecl A garnet (UV66/09-A) is identical to that of the garnet. In the rims of Ecl garnets B (six samples) and C (two samples), a decrease in $\mathrm{FeO}$ (by 0.7-7.9 wt \%) with respect to the composition of garnet is noticeable. The amounts of silica, alumina, and calcium in these rims are sometimes higher than those in garnets. An impurity of $\mathrm{Na}_{2} \mathrm{O}$ (up to $2.2 \mathrm{wt} . \%$ ) is observed in almost all rims, whereas noticeable amounts of $\mathrm{K}_{2} \mathrm{O}(2.04 \mathrm{wt} . \%)$ were noted only in Ecl B UV156/10 (Table 3, Ecl). This confirms that plagioclase, amphibole, and sodalite are more abundant in Ecl B, and especially $\mathrm{C}$, than phlogopite and potassium feldspar. 
Table 3. Chemical composition (wt.\%) of garnet and bulk composition of kelyphite rim.

\begin{tabular}{|c|c|c|c|c|c|c|c|c|c|c|c|c|c|}
\hline Paragenesis & Sample & G/R & $\mathrm{SiO}_{2}$ & $\mathrm{TiO}_{2}$ & $\mathrm{Al}_{2} \mathrm{O}_{3}$ & $\mathrm{Cr}_{2} \mathrm{O}_{3}$ & $\mathrm{FeO}$ & $\mathrm{MnO}$ & $\mathrm{MgO}$ & $\mathrm{CaO}$ & $\mathrm{Na}_{2} \mathrm{O}$ & $\mathrm{K}_{2} \mathrm{O}$ & Total \\
\hline \multirow{28}{*}{ MHD } & \multirow[b]{2}{*}{ UV12/01-1 } & Grt & 41.4 & 0.00 & 16.6 & 8.54 & 7.19 & 0.38 & 21.9 & 3.38 & 0.01 & 0.00 & 99.3 \\
\hline & & rim1 & 41.9 & 0.01 & 17.0 & 8.31 & 7.16 & 0.42 & 21.3 & 3.28 & 0.02 & 0.02 & 99.5 \\
\hline & \multirow{2}{*}{ UV26/10-1 } & Grt & 41.7 & 0.00 & 16.2 & 8.89 & 6.91 & 0.40 & 22.6 & 2.35 & 0.02 & 0.01 & 99.1 \\
\hline & & rim1 & 41.8 & 0.00 & 16.1 & 9.23 & 6.97 & 0.36 & 22.4 & 2.28 & 0.00 & 0.00 & 99.2 \\
\hline & \multirow{2}{*}{ UV667/11 } & Grt & 41.1 & 0.06 & 15.1 & 10.9 & 6.96 & 0.40 & 21.4 & 3.54 & 0.00 & 0.01 & 99.4 \\
\hline & & rim1 & 41.3 & 0.04 & 15.7 & 9.94 & 6.91 & 0.39 & 21.6 & 3.47 & 0.03 & 0.01 & 99.4 \\
\hline & \multirow{2}{*}{ UV159/10-2 } & Grt & 41.1 & n.d. & 15.4 & 11.3 & 6.93 & 0.41 & 19.3 & 5.41 & 0.00 & 0.00 & 99.9 \\
\hline & & rim1 & 39.4 & 0.02 & 14.7 & 11.2 & 7.18 & 0.55 & 20.2 & 5.20 & 0.33 & 0.52 & 99.3 \\
\hline & \multirow[b]{2}{*}{ UV157/10-1 } & Grt & 41.4 & n.d. & 16.9 & 8.86 & 7.80 & 0.51 & 20.9 & 3.67 & 0.03 & 0.00 & 100 \\
\hline & & rim1 & 39.9 & 0.02 & 16.4 & 9.53 & 7.76 & 0.49 & 21.9 & 3.51 & 0.06 & 0.50 & 100 \\
\hline & \multirow{2}{*}{ UV526/11 } & Grt & 41.0 & n.d. & 15.6 & 10.8 & 6.99 & 0.48 & 21.6 & 3.41 & 0.00 & 0.00 & 99.9 \\
\hline & & rim1 & 38.9 & n.d. & 14.8 & 10.9 & 7.28 & 0.66 & 22.5 & 3.29 & 0.10 & 1.22 & 99.7 \\
\hline & \multirow{2}{*}{ UV71/10 } & Grt & 41.4 & n.d. & 15.3 & 10.8 & 7.50 & 0.44 & 22.7 & 1.67 & 0.00 & 0.00 & 99.7 \\
\hline & & rim1 & 37.9 & n.d. & 14.6 & 11.8 & 7.54 & 0.58 & 23.7 & 1.25 & 0.22 & 1.25 & 98.8 \\
\hline & \multirow{2}{*}{ UV850/09 } & Grt & 41.4 & n.d. & 15.8 & 10.5 & 6.95 & 0.37 & 22.1 & 2.96 & 0.00 & 0.00 & 100 \\
\hline & & rim1 & 39.8 & n.d. & 15.6 & 10.6 & 6.96 & 0.00 & 22.1 & 1.90 & 0.43 & 1.61 & 98.9 \\
\hline & \multirow{2}{*}{ UV524/11 } & Grt & 40.7 & n.d. & 14.1 & 11.9 & 7.50 & 0.67 & 20.0 & 4.69 & 0.00 & 0.00 & 99.6 \\
\hline & & rim1 & 37.0 & n.d. & 13.8 & 13.3 & 7.68 & 0.53 & 21.4 & 4.21 & 0.50 & 1.04 & 99.3 \\
\hline & \multirow{2}{*}{ UV113/09 } & Grt & 41.8 & n.d. & 16.5 & 9.56 & 6.24 & 0.40 & 22.7 & 2.36 & 0.00 & 0.00 & 99.5 \\
\hline & & rim1 & 38.0 & n.d. & 15.7 & 9.85 & 7.02 & 0.62 & 24.4 & 1.59 & 0.72 & 1.85 & 99.7 \\
\hline & \multirow{2}{*}{ UV702/13 } & Grt & 41.1 & n.d. & 15.0 & 11.3 & 7.06 & 0.52 & 22.1 & 2.42 & 0.00 & 0.00 & 99.6 \\
\hline & & rim1 & 36.8 & n.d. & 14.2 & 12.2 & 7.20 & 0.44 & 23.1 & 2.64 & 0.73 & 1.08 & 98.5 \\
\hline & \multirow{2}{*}{ UV704/13 } & Grt & 41.1 & n.d. & 15.3 & 11.6 & 6.82 & 0.00 & 22.7 & 1.58 & 0.00 & 0.00 & 99.1 \\
\hline & & rim1 & 39.3 & n.d. & 14.7 & 11.3 & 6.99 & 0.53 & 23.1 & 1.44 & 0.54 & 0.73 & 98.8 \\
\hline & \multirow{2}{*}{ UV180/10 } & Grt & 40.6 & n.d. & 13.6 & 13.1 & 7.10 & 0.52 & 17.5 & 7.79 & 0.00 & 0.00 & 101 \\
\hline & & rim1 & 37.0 & n.d. & 12.8 & 14.7 & 8.20 & 0.53 & 18.4 & 6.80 & 0.82 & 1.19 & 100 \\
\hline & \multirow{2}{*}{ UV86/01 } & Grt & 42.4 & n.d. & 18.2 & 8.16 & 6.97 & 0.43 & 23.5 & 0.97 & 0.00 & 0.00 & 101 \\
\hline & & rim1 & 35.9 & n.d. & 18.0 & 8.73 & 7.90 & 0.43 & 25.3 & 0.74 & 0.45 & 0.49 & 98.0 \\
\hline \multirow{6}{*}{ ShP } & & Grt & 40.5 & 0.82 & 14.9 & 9.50 & 7.14 & 0.35 & 19.6 & 6.35 & 0.00 & 0.00 & 99.2 \\
\hline & UV207/10 & rim1 & 38.5 & 0.87 & 13.2 & 9.66 & 7.26 & 0.52 & 20.0 & 6.52 & 0.66 & 0.70 & 97.9 \\
\hline & & Grt & 41.8 & 0.00 & 17.3 & 7.67 & 7.33 & 0.36 & 20.4 & 5.92 & 0.00 & 0.00 & 101 \\
\hline & UV33/10 & rim1 & 39.6 & 0.52 & 15.5 & 7.40 & 8.39 & 0.48 & 23.0 & 4.87 & 0.38 & 0.14 & 100 \\
\hline & & Grt & 42.9 & 0.45 & 21.3 & 1.94 & 8.01 & 0.34 & 22.1 & 4.44 & 0.00 & 0.00 & 101 \\
\hline & UV831/09 & rm1 & 39.2 & 0.93 & 18.8 & 2.48 & 7.09 & 0.25 & 22.9 & 5.43 & 1.79 & 1.37 & 101 \\
\hline & & Grt-A & 41.4 & 1.23 & 22.1 & 0.00 & 11.4 & 0.32 & 17.1 & 6.03 & 0.28 & 0.00 & 100 \\
\hline & UV66/09 & rim1 & 41.3 & 1.13 & 22.1 & 0.00 & 11.2 & 0.45 & 17.2 & 5.47 & 0.43 & 0.00 & 99.3 \\
\hline & & Grt-B & 40.0 & 0.17 & 22.0 & 0.00 & 13.7 & 0.32 & 12.8 & 9.51 & 0.00 & 0.00 & 98.4 \\
\hline & UV156/10 & rim1 & 39.2 & 0.52 & 18.0 & 0.00 & 11.8 & 0.37 & 13.2 & 7.47 & 1.20 & 2.04 & 93.8 \\
\hline & & Grt-B & 39.9 & n.d. & 22.1 & 0.00 & 16.2 & 0.30 & 9.63 & 11.0 & 0.00 & 0.00 & 99.1 \\
\hline & U6/10 & rim1 & 40.4 & n.d. & 21.7 & 0.00 & 14.9 & 0.28 & 9.60 & 11.2 & 0.92 & 0.00 & 98.9 \\
\hline & JV13/10 & Grt-B & 40.2 & n.d. & 22.4 & 0.00 & 18.4 & 0.48 & 9.68 & 10.0 & 0.00 & 0.00 & 101 \\
\hline & Uv13/10 & rim1 & 39.8 & n.d. & 22.2 & 0.00 & 17.7 & 0.37 & 9.63 & 10.2 & 0.97 & 0.00 & 101 \\
\hline Ecl & & Grt-B & 40.4 & 0.52 & 22.1 & 0.00 & 16.3 & 0.44 & 11.7 & 9.30 & 0.00 & 0.00 & 101 \\
\hline & UV211/10 & rim1 & 42.3 & 0.75 & 23.9 & 0.00 & 8.40 & 0.00 & 7.78 & 11.0 & 2.20 & 0.30 & 96.9 \\
\hline & & Grt-B & & 0.70 & 22.5 & 0.00 & 11.9 & 0.00 & 13.0 & 10.8 & 0.00 & 0.00 & 100 \\
\hline & UV70/09 & rim1 & 39.7 & 0.62 & 22.3 & 0.00 & 11.1 & 0.00 & 13.6 & 11.4 & 0.50 & 0.00 & 99.2 \\
\hline & & Grt-B & 40.1 & 0.30 & 22.2 & 0.15 & 14.1 & 0.23 & 11.0 & 11.7 & 0.00 & 0.00 & 99.8 \\
\hline & UV150/09 & rim1 & 40.0 & 0.22 & 22.5 & 0.15 & 13.5 & 0.30 & 10.6 & 10.6 & 1.39 & 0.00 & 99.3 \\
\hline & & Grt-C & 39.8 & 0.00 & 22.4 & 0.00 & 11.2 & 0.00 & 4.69 & 22.1 & 0.00 & 0.00 & 100 \\
\hline & UV134/10 & rim1 & 39.8 & 0.38 & 22.6 & 0.00 & 10.9 & 0.00 & 4.53 & 21.8 & 0.55 & 0.00 & 101 \\
\hline & & Grt-C & 39.0 & 0.20 & 21.6 & 0.00 & 19.0 & 0.40 & 5.62 & 13.6 & 0.00 & 0.00 & 99.5 \\
\hline & UV662/11 & $\operatorname{rim} 1$ & 39.0 & 0.00 & 20.9 & 0.00 & 16.9 & 0.49 & 4.96 & 14.8 & 0.00 & 0.00 & 97.1 \\
\hline
\end{tabular}

2. Rim2. $\mathrm{Al}^{\mathrm{IV}}$ content in minerals in the rims of this type of peridotite and eclogite parageneses is lower than for similar minerals in rim1, but higher than in rockforming minerals (Table 2). of pyroxenes and phlogopite is higher than in rim1, whereas the opposite trend is observed for the spinel of all parageneses due to the sharply increasing Fe component. This is most clearly manifested in spinel of Ecl C. In rim2 spinels of peridotite parageneses, a sharp increase in $\mathrm{TiO} 2$ was observed compared to similar spinels of rim1 (from 0.5 to $2 \mathrm{wt} . \%$ ). The same was observed for phlogopite of all three parageneses: $\mathrm{The}^{\mathrm{TiO}_{2}}$ variations in rims 1 and 2 were (wt.\%): 0.4-1, 1.7-2.2, and 0.7-2.1 for MHD, ShP, and Ecl, respectively. The chemical composition of the exotic layered phase (shown as an asterisk in Figure 2c,e and described in the section Classification) varied in different samples (wt.\%): $\mathrm{SiO}_{2} 12-28$; 
$\mathrm{TiO}_{2}$ 0-0.4; $\mathrm{Al}_{2} \mathrm{O}_{3} 3-10 ; \mathrm{Cr}_{2} \mathrm{O}_{3}$ 0.5-3; FeO 1.5-12; $\mathrm{MnO} 0-0.3 ; \mathrm{MgO} 32-44 ; \mathrm{CaO} 0-1.7 ;$ $\mathrm{Na}_{2} \mathrm{O} 0-0.4 ; \mathrm{K}_{2} \mathrm{O} 0-0.8 ; \mathrm{SO}_{3} 0-1.8 ; \mathrm{Cl} 3-6.5$. Unfortunately, the phase was impossible to identify according to the available databases.

3. Rim 3. Average values for main components of the spinel and phlogopite of this rim for MHD and Ecl A are shown in Table 2. However, the composition of the minerals changes markedly from the border with the garnet to the border with kimberlite. In spinel, the content of iron and titanium increases, and an increase in ulvöspinel and magnetite molecules occurs [42]. The phlogopite chemistry of MHD varies as follows: Decreasing $\mathrm{Al}_{2} \mathrm{O}_{3}$ (15.1 to 8.73 wt.\%), $\mathrm{Cr}_{2} \mathrm{O}_{3}$ (4.86 to 0 wt.\%), and $\mathrm{FeO}$ (5.85 to 3.73 wt. \%), but increasing $\mathrm{MgO}$ (21.9 to $27.4 \mathrm{wt.} \%$ ) and $\mathrm{BaO}$ (0 to $6.51 \mathrm{wt} . \%)$, as the analysis of sample UV159/10-2 shows. Phlogopite with the highest $\mathrm{BaO}$ component contains $1.34 \mathrm{wt} . \% \mathrm{~F}$, but phlogopite from kimberlite, adjacent to rim3, contains $0.9 \mathrm{wt} . \% \mathrm{Ba} 0$, and is free from F. Rims of this type occur in three other samples; phlogopite in one of them (sample UV702/13) contains $5.43 \mathrm{wt} . \% \mathrm{Ca} 0$ and $4.74 \mathrm{wt} . \%$ $\mathrm{Cl}$, possibly due to fine ingrowths of calcite and an unidentified chlorine-containing phase (asterisk in Figure 2c,e); the probability of the presence of sodalite is excluded, because phlogopite does not contain $\mathrm{Na}_{2} \mathrm{O}$. In the phlogopite of the Ecl A rim, the major-element composition changes gradually from garnet to kimberlite: Increasing $\mathrm{Al}_{2} \mathrm{O}_{3}$ (11.5 to 15.9 wt.\%), $\mathrm{MgO}$ (from 19.1 to $25.6 \mathrm{wt} . \%$ ), and $\mathrm{BaO}$ (0.55 to $3.74 \mathrm{wt} . \%$ in the outer zone) but decreasing $\mathrm{FeO}$ (9.13 to $2.86 \mathrm{wt} . \%$ in the outer zone). Phlogopite from kimberlite adjacent to the rim contains $0.9 \mathrm{wt} . \% \mathrm{BaO}$. Phlogopite from the rim encloses fine calcite grains that become fewer toward kimberlite: $\mathrm{CaO}$ decreasing from 7.5 to $0 \mathrm{wt} . \%$. The minerals of $\operatorname{rim} 3$ on Ecl garnet are free from $\mathrm{Cr}_{2} \mathrm{O}_{3}$.

4. MHD rim4. The $\mathrm{Cr}_{2} \mathrm{O}_{3}$ content in some rim zones is higher than that in garnet: $\mathrm{Cr}_{2} \mathrm{O}_{3}$ variations (wt.\%) in garnets and their rims are 9.31-10.58 and 6.36-11.93, respectively (analyses of two points with extreme $\mathrm{Cr}_{2} \mathrm{O}_{3}$ content are shown in Table 2). Some rims have chains of spinel grains on the periphery (Figure 2i), but their sizes (about one micron or less) are too small for good analysis.

5. MHD rim5. Seven different areas of rim5 were analyzed and the following results were obtained (wt.\%): $\mathrm{SiO}_{2}$ 29.87-37.89; $\mathrm{TiO}_{2} 0-0.3 ; \mathrm{Al}_{2} \mathrm{O}_{3}$ 5.03-10.56; $\mathrm{Cr}_{2} \mathrm{O}_{3}$ 6.85-10.76; $\mathrm{FeO}$ 6.56-8.10; $\mathrm{MnO} 0-0.49 ; \mathrm{MgO}$ 6.52-15.60; $\mathrm{CaO} 11.46-24.09 ; \mathrm{Na}_{2} \mathrm{O}$ 0-0.27; $\mathrm{K}_{2} \mathrm{O}$ 2.10-3.99; total 82.32-96.51. The deficit of the sum indicates the presence of water (most obvious in this situation), and volatile (fluorine, chlorine, etc.) or unaccounted components. This deficit cannot be explained by hydrogarnet due to the presence of $3 \mathrm{wt} . \% \mathrm{~K}_{2} \mathrm{O}$; furthermore, it cannot be amphibole due to the large amount of $\mathrm{CaO}$ present, in addition to the complete absence of $\mathrm{Na}_{2} \mathrm{O}$ in the presence of $\mathrm{K}_{2} \mathrm{O}$. Moreover, proceeding from the inhomogeneity (light and dark areas in the BSE mode), this is not one phase, but a mixture (apparently, very thin intergrowths) of several phases. The quantitative variations of the components make it possible to assume that these are the same phases, but in different proportions. The large amount of $\mathrm{CaO}$ suggests that one of the phases is calcite. The presence of 34-37 wt. $\% \mathrm{SiO}_{2}$ simultaneously with $3-4 \mathrm{wt} . \% \mathrm{~K}_{2} \mathrm{O}$ and the deficiency of the sum indicates a high probability of the presence of phlogopite. However, the combination of calcite and phlogopite will result in a much larger deficit of the sum than in our analyses. In addition, the presence of calcite greatly reduces the silicon content. Therefore, potassium feldspar (a phase with high content of $\mathrm{K}, \mathrm{Si}$, and a normal sum of components), in addition to alumina clinopyroxene and Ca-plagioclase (phases with high content of $\mathrm{Ca}, \mathrm{Si}$, and a normal sum of components) are probably present here. The quantity of 7-9 wt. $\% \mathrm{Cr}_{2} \mathrm{O}_{3}$, in addition to similar amounts of $\mathrm{FeO}$ and $\mathrm{Al}_{2} \mathrm{O}_{3}$, allows a small amount of $\mathrm{Cr}$-spinel. Thus, according to our reasoning, rim5 comprises very thin intergrowths of calcite, phlogopite, and $\mathrm{Cr}$-spinel. This is the most likely set of minerals based on common sense and the mineralogy of the other types of rim. Simple calculations give quite wide possible variations in the combinations of the above minerals: $5 \mathrm{cpx}+4 \mathrm{phl}+1 \mathrm{cat}+1 \mathrm{spl} ; 6 \mathrm{cpx}+2 \mathrm{phl}+3 \mathrm{cat}+2 \mathrm{spl}+\mathrm{kfs} ; 4 \mathrm{cpx}+5 \mathrm{phl}+$ $3 c a t+2 \mathrm{spl}+$ Ca-pl; $3 \mathrm{cpx}+2 \mathrm{cat}+1 \mathrm{spl}+2 \mathrm{kfs}$, etc. 


\subsubsection{Rare-Earth Data}

Rims 1 and 2 cannot be separated with certainty when analyzing rare earths due to their proximity and frequent penetration into each other and considering the width of the analyzing beam (about $70 \mu \mathrm{m}$ ). Therefore, this section uses the term rim $1 / 2$. The analyses of main, rare-earth elements of peridotite garnets, and rare-earth elements of surrounding rims obtained by the methods described above, are provided in Tables A1-A3, respectively (Appendix B), and are shown in Figure 5. Used as an external standard, NIST 610 glass is well suited for the analysis of minerals of enriched rocks (sheared peridotites) but does not provide adequate sensitivity in the case of minerals of extremely depleted rocks (MHD), which is reflected in the degree of smoothness of normalized spidergrams (Figure 5). However, the results obtained make it possible to operate with average values and draw conclusions about the general direction of the processes. MHD garnets, which are slightly susceptible to enrichment processes [24], usually demonstrate a sinusoidal distribution of rare-earth elements with peaks in the LREE [43]. This distribution is generally traced for the MHD garnets of this study (Figure 5a). The maximum values of $\mathrm{Ce}-\mathrm{Nd}$ and minimum Dy-Tm are clearly manifested. ShP garnets are divided into two groups according to the REE pattern shapes [44]. The primitive mantle normalized REE distribution of four ShP garnets is characterized by a flat shape from Lu to Gd and a drop in values down up to La, whereas the REE distribution diagram of the ShP garnet in sample UV207/09 has a sinusoidal shape (Figure 5a). The primitive mantle-normalized REE distribution in rim1/2 of both peridotite parageneses is similar to that for their garnets in the areas of MREE and HREE; however, the rims show a sharp enrichment in La-Ce (6-10-fold greater than in garnet) (Figure 5b). Rim3 MHD and ShP are enriched in LREE (10-100-fold greater than in primitive mantle) and MREE (5-10-fold greater than in primitive mantle). However, in contrast to the rim3 ShP spidergram, which practically does not change the values in the region from $\mathrm{Lu}$ to $\mathrm{Ho}$, the REE distribution diagram for rim3 MHD is characterized by a gradual increase in the values from $\mathrm{Lu}$ to $\mathrm{La}$.
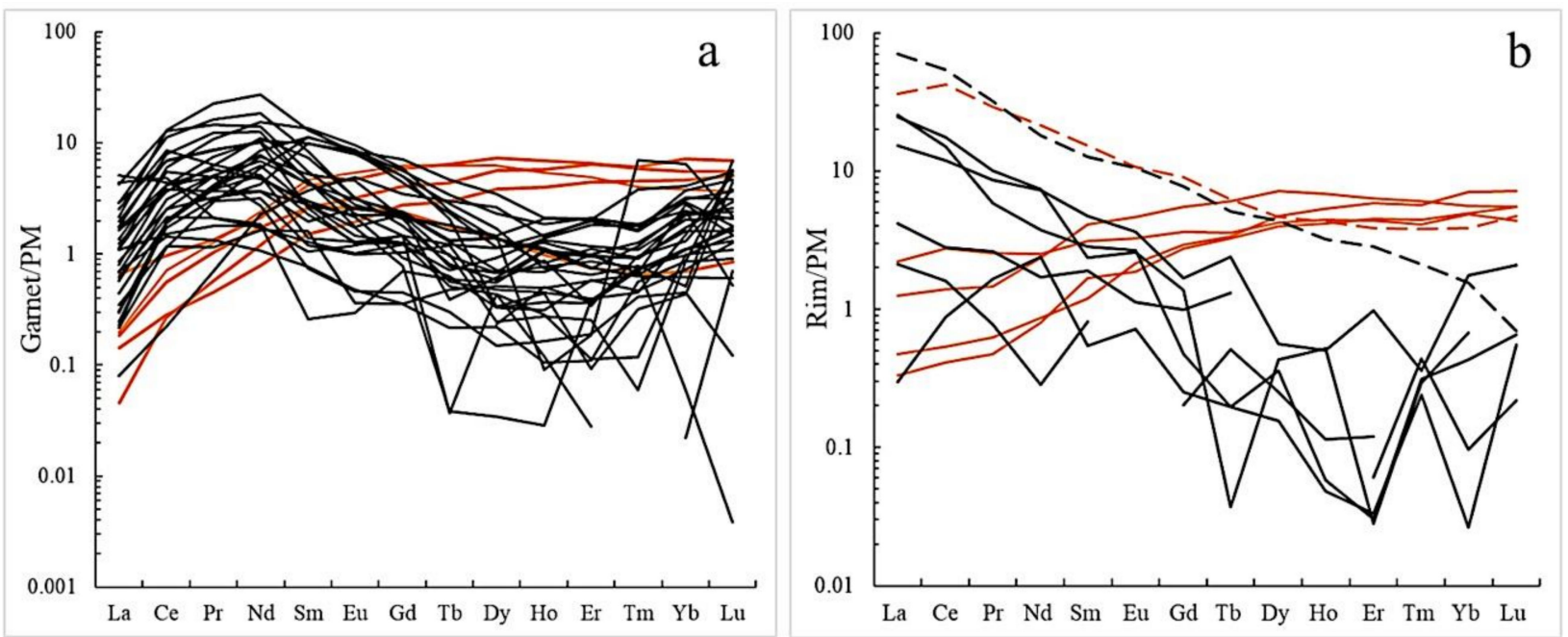

Figure 5. Primitive mantle normalized (after [45]) REE patterns of studied peridotite garnets and kelyphites: (a) Grt REE patterns (thirty-one MHD samples—black solid line, five ShP samples—orange solid line); (b) kelyphite REE patterns (six MHD rim1-2—black solid line; one MHD rim3—black dashed line; four ShP rim1/2—orange solid line, one ShP rim3-orange dashed line).

\section{Discussion}

\subsection{Distribution of Main Components in Minerals of Kelyphite Rims}

As mentioned above, the pyroxenes and spinel in rims 1 and 2 are enriched in alumina (Table 2). Moreover, the percentage of the Tschermak component in orthopyroxene is higher than $(\mathrm{MHD}, \mathrm{ShP})$ or roughly similar $(\mathrm{Ecl})$ to that in clinopyroxene. Part of the alumina 
in the latter is bound with $\mathrm{Na}$, forming a Jadeite component. However, this com-ponent in the clinopyroxene of the rim is less than that in the rock-forming clinopyroxene for enriched parageneses (ShP and Ecl). It is likely that, during the rim formation, Na is introduced into the system, and participates in the formation of other minerals: Amphibole, sodalite, and plagioclase. The growth of $\mathrm{Mg}$ \# in orthopyroxene from rim1 to rim2 is associated not only with a decrease in $\mathrm{FeO}$ in its composition (due to an increase in this component in spinel), but also with a decrease in the share of the Tschermak component. $\mathrm{TiO}_{2}$ enrichment is most pronounced in rim2 for all parageneses, but the distribution between minerals is different. In rim2 of MHD, the $\mathrm{TiO} 2$ is mainly concentrated in spinel and, to a lesser extent, in phlogopite; in pyroxenes, its concentration is practically the same as in rim1. In rim2 of ShP, titanium is distributed between spinel and phlogopite, and in orthopyroxene its concentration decreases. In rim 2 of Ecl, the overwhelming majority of $\mathrm{TiO}_{2}$ is in phlogopite, in spinel its amount increases insignificantly compared to that in rim1, and in orthopyroxene it decreases. The compositions of the rim minerals are determined by the composition of the garnet, due to which they are formed. Metasomatic agents that affect the rocks also play an important role. It is obvious that the formation of rim2 was accompanied by an inflow of titanium, which was distributed depending on the initial conditions of the system. Rim3 is not fully represented here. However, based on the available data, the concentration of titanium in the phlogopites of these rims is lower than in the phlogopites of rim2, whereas the average $\mathrm{TiO}_{2}$ value in spinel (from 29 analyses in different places of the rim) in rim3 MHD is extremely high (Table 2) because of the significant contribution of ulvöspinel [42]. The FeO concentration in the phlogopite-rim 3 of Ecl is lower than that in rim2. However, the contents of this component increase from rim2 to rim3 in phlogopite and spinel of MHD and ShP. The enrichment in $\mathrm{Cr}_{2} \mathrm{O}_{3}(6.36-11.93 \mathrm{wt} . \%)$ is a distinctive feature of the rim4 MHD phlogopite (Table 2). Similar contents of $\mathrm{Cr}_{2} \mathrm{O}_{3}(6.85-9.38 \mathrm{wt} . \%)$ were observed in MHD rim5 in addition to high contents of $\mathrm{CaO}$ (17.87-24.09 wt.\%) (Analytical data section). However, MHD rim5, as mentioned above, comprises very thin intergrowths of several phases; it is not possible to analyze the distribution of chemical components in individual minerals of this rim.

Thus, each type of kelyphite demonstrates a clear enrichment with a certain compo-nent: Rim1- $\mathrm{MgO}$ and alkalis; rim2- $\mathrm{TiO}_{2} ; \mathrm{rim} 3-\mathrm{FeO}$ and $\mathrm{TiO}_{2} ; \mathrm{rim} 4-\mathrm{Cr}_{2} \mathrm{O}_{3}$; and rim5- Ca0, suggesting the stage-by-stage enrichment of mantle rocks with deep melts/fluids of varying compositions. However, this should be interpreted flexibly, allowing the inflow of some amount, for example, $\mathrm{FeO}$ or $\mathrm{CaO}$ at the stage of formation of rim 1 or rim2, and remembering the enrichment with alkalis continues during the formation of all types of rims. Therefore, the reactions given below, although written considering the compositions of the initial garnets and variations in the chemical compositions of minerals in different rims, are nonetheless models and are intended to highlight certain trends. Overall, they represent separate fragments of a uniform complex process of formation of kelyphite rims as a result of metasomatic impact on mantle rocks. In addition, it is obvious that under such an effect, the scale and rate of change in the PT parameters of the process and its redox characteristics play an important role. The heterogeneity of the upper mantle also implies compositional variability in both the parent systems and the fluid/melts acting on them. Finally, the penetrating fluid/melt clearly interacts not only with garnet, but also with adjacent olivine or pyroxene. Thus, both minerals take part in the formation of rims in one way or another, but garnet appears to play a key role. In this study, attention and preference is given precisely to the interaction with garnet. First, it is the "carrier" of these rims. Second, it has a more complex chemical composition, which allows it to form a wide variety of other minerals with a minimum inflow of additional components.

\subsection{Possible Rim Forming Reactions and Trends}

As mentioned above, the compositions of rim 1 and garnets in peridotites are sometimes completely identical. In most cases they are similar, with the difference that in the rim, generally, the contents of $\mathrm{SiO}_{2}, \mathrm{Al}_{2} \mathrm{O}_{3}$ are reduced, the content of $\mathrm{MgO}$ is increased, 
and impurities of $\mathrm{K}_{2} \mathrm{O}$ and $\mathrm{Na}_{2} \mathrm{O}$ appear (Table 3). Therefore, the kelyphitic rims may result from the effect of deep-seated hot magnesian melts rich in alkalis and water. The melts, in turn, were produced by partial melting of enriched mantle parageneses such as pyroxenite and megacrystalline garnet affected by carbonatite metasomatism [43]. They are not purely basic, and thus depleted in silica and contain a carbonatite (in this case, most likely magnesite) component. The rim is formed rapidly but not immediately. A general tendency was observed of a gradual (Figure 2a) or abrupt (Figure 2d) increase in the constituent crystallites and a redistribution of their amounts. The initial stage of the rim formation is probably associated with the release of pressure and a rise in temperature at the time of cracking and friction in the collision zone. This is an extremely rapid isochemical process. The finest symplectites of two pyroxenes extremely enriched in alumina are formed. Considering that in both pyroxenes of the rim the Tschermak component is represented by Mg-Tschermak (see Analytical data, Rim1), the decomposition of garnet can be described by the following reaction:

$$
2 \mathrm{Ca}_{0.5} \mathrm{Mg}_{2.5} \mathrm{Al}_{2} \mathrm{Si}_{3} \mathrm{O}_{12}(\mathrm{Grt}) \rightarrow\left\{\mathrm{Mg}_{2} \mathrm{Si}_{2} \mathrm{O}_{6} \cdot \mathrm{MgAl}_{2} \mathrm{SiO}_{6}\right\}(\mathrm{Opx})+\left\{\mathrm{CaMgSi}_{2} \mathrm{O}_{6} \cdot \mathrm{MgAl}_{2} \mathrm{SiO}_{6}\right\} \text { (Cpx). }
$$

Here and in subsequent reactions, unless otherwise stated, the composition calculated as the average for thirty-two MHD garnets from this study (Appendix B, Table A1) was taken as the initial composition of the garnet.

However, in general, in addition to two pyroxenes, rim1 contains spinel and a small amount of phlogopite. Thus, when writing the basic reaction of the formation of this rim, it is necessary to consider the following: (1) The percentage of mineral phases in the border (similar amounts of clinopyroxene, orthopyroxene, spinel, and scanty phlogopite); (2) deficiency of silica in the rim (reaction products); and (3) input of components with melt/fluid (magnesium, potassium, water). The chemical compositions of the formed minerals in the reaction below are the average compositions of pyroxenes, spinel, and phlogopite given in Table 2 (MHD, Rim1):

$1.5 \mathrm{Ca}_{0.5} \mathrm{Mg}_{2.5} \mathrm{Al}_{2} \mathrm{Si}_{3} \mathrm{O}_{12}(\mathrm{GRT})+\left[0.15 \mathrm{MgO}+0.05 \mathrm{~K}+0.05 \mathrm{H}_{2} \mathrm{O}\right]$ (melt/fluid) $\rightarrow 0.05 \mathrm{KMg}_{3} \mathrm{AlSi}_{3} \mathrm{O}_{10}(\mathrm{OH})_{2}(\mathrm{Phl})$

$+\mathrm{MgAl}_{2} \mathrm{O}_{4}(\mathrm{Spl})+\mathrm{Mg}_{1.75} \mathrm{Al}_{0.5} \mathrm{Si}_{1.75} \mathrm{O}_{6}(\mathrm{Opx})+\mathrm{Ca}_{0.75} \mathrm{MgAl}_{0.45} \mathrm{Si}_{1.8} \mathrm{O}_{6}(\mathrm{Cpx})+\left[0.8 \mathrm{SiO}_{2}\right]$ (deficiency of silica),

where $\mathrm{Al}=\mathrm{Al}+\mathrm{Cr} ; \mathrm{Mg}=\mathrm{Mg}+\mathrm{Fe}$; $\mathrm{Ca}$ in clinopyroxene $=\mathrm{Ca}+\mathrm{Na} ; \mathrm{K}$ in phlogopite $=\mathrm{K}+\mathrm{Na}$; the indices were rounded.

Then, the system attempts to stabilize the parameters, and the PT tend to the initial parameter values. Therefore, due to the continued interaction with the melt/fluid flowing through the cracks, high-alumina pyroxenes (px1), which appeared at the reaction front, in addition to participating in the formation of phlogopite and the growth/enlargement of spinel, form low-alumina pyroxenes (px2). In this case, the iron content in the newly formed pyroxenes decreases, whereas it increases in the newly formed spinel and phlogopite; in spinel, in addition, the titanium content increases (Table 2, Peridotites, Rim1, 2). This can be schematically illustrated as follows:

$\left\{2.5 \mathrm{Fe}_{2} \mathrm{Si}_{2} \mathrm{O}_{6} \cdot 2 \mathrm{MgAl}_{2} \mathrm{SiO}_{6}\right\}(\mathrm{Opx} 1)+\left\{\mathrm{CaFeSi}_{2} \mathrm{O}_{6} \cdot \mathrm{MgAl}_{2} \mathrm{SiO}_{6}\right\}(\mathrm{Cpx} 1)+\left[4 \mathrm{MgO}+\mathrm{K}_{2} \mathrm{O}+2 \mathrm{H}_{2} \mathrm{O}+\mathrm{TiO}_{2}\right]$ (melt $/$ fluid) $\rightarrow 2 \mathrm{KMg}_{2} \mathrm{FeAlSi}_{3} \mathrm{O}_{10}(\mathrm{OH})_{2}(\mathrm{Phl})+\left\{2 \mathrm{FeAl}_{2} \mathrm{O}_{4} \cdot \mathrm{Fe}_{2} \mathrm{TiO}_{4}\right\}(\mathrm{Spl})+\mathrm{Mg}_{2} \mathrm{Si}_{2} \mathrm{O}_{6}(\mathrm{Opx} 2)+\mathrm{CaMgSi}_{2} \mathrm{O}_{6}(\mathrm{Cp} 2)$.

Phlogopite in the clinopyroxene-free rim of strongly depleted garnets may form due to the $\mathrm{Al}$ orthopyroxene and fluid, by the reaction transformed from [46]:

$$
\left.\left\{5 \mathrm{Mg}_{0.6} \mathrm{Fe}_{0.4} \mathrm{SiO}_{3} \cdot \mathrm{MgAl}_{2} \mathrm{SiO}_{6}\right\}(\mathrm{Opx})+\left[\mathrm{K}_{2} \mathrm{O}+2 \mathrm{H}_{2} \mathrm{O}\right] \text { (melt } / \text { fluid }\right) \rightarrow 2 \mathrm{KMg}_{2} \mathrm{FeAlSi}_{3} \mathrm{O}_{10}(\mathrm{OH})_{2}(\mathrm{Phl}) \text {. }
$$

Rim1 of six peridotites (four MHD and two ShP) contained both phlogopite and amphibole, which indicates high water activity [47], in addition to the possibility of the same participation of sodium and potassium in the alkaline component of the fluid/melt during the formation of these rims. In addition, the alumina content of pyroxenes was lower than the average for rims of this type. Taking the average composition of garnets of 
the six above-mentioned peridotites as the initial garnet composition, the process can be schematically represented as follows:

$$
\begin{gathered}
7 \mathrm{Ca}_{4 / 7} \mathrm{Mg}_{17 / 7} \mathrm{Al}_{2} \mathrm{Si}_{3} \mathrm{O}_{12}(\mathrm{Grt})+[3 \mathrm{MgO}+ \\
+\mathrm{NaCa}_{2}\left(\mathrm{Mg}_{4} \mathrm{Al}\right) \mathrm{Si}_{6} \mathrm{Al}_{2} \mathrm{O}+0.5 \mathrm{O}_{22} \mathrm{OH}+2 \mathrm{H}_{2} \mathrm{O}(\mathrm{Amp})+3 \mathrm{MgAl}_{2} \mathrm{O}_{4}(\mathrm{Spl})+\left\{3 \mathrm{Mg}_{2} \mathrm{Si}_{2} \mathrm{O}_{6} \cdot \mathrm{MgAl}_{2} \mathrm{SiO}_{6}\right\}(\mathrm{Opx}) \\
+\left\{2 \mathrm{CaMgSi}_{2} \mathrm{O}_{6} \cdot \mathrm{MgAl}_{2} \mathrm{SiO}_{6}\right\}(\mathrm{Cpx}) \\
+\mathrm{Nal}_{2}(\mathrm{Phl}) \\
\end{gathered}
$$

where $\mathrm{Al}=\mathrm{Al}+\mathrm{Cr} ; \mathrm{Mg}=\mathrm{Mg}+\mathrm{Fe}$.

In rim2 of some studied peridotites and Ecl B UV13/10, Fe-olivine is present in the intergrowth with pyroxenes and spinel (e.g., Figure 2d). Olivine formation in the rim can be caused by a deficiency of silica in the system, when instead of some part of orthopyroxene, olivine is formed. As mentioned above, in the pyroxenes of rim2, in comparison with those in rim1, not only the alumina content, but also the iron content, decreases. In spinel and phlogopite, on the contrary, the iron content increases (see Table 2 and Reaction 3). In this case, due to the ferrosilite component of pyroxene-1, less ferrous pyroxene- 2 is formed; olivine, which is more ferrous than rock-forming olivine, is also formed:

$2\left\{\mathrm{Fe}_{2} \mathrm{Si}_{2} \mathrm{O}_{6} \cdot \mathrm{MgAl}_{2} \mathrm{SiO}_{6}\right\}(\mathrm{Opx} 1)+[3 \mathrm{MgO}]($ melt $/$ fluid $) \rightarrow 2 \mathrm{FeAl}_{2} \mathrm{O}_{4}(\mathrm{Spl})+2.5 \mathrm{Mg}_{2} \mathrm{Si}_{2} \mathrm{O}_{6}(\mathrm{Opx} 2)+\mathrm{Fe}_{2} \mathrm{SiO}_{4}(\mathrm{Ol})$.

It should be noted that an increase in the iron content of newly formed minerals can be caused not only by the redistribution of components between minerals, but also by the presence of a certain amount of $\mathrm{Fe} 0 / \mathrm{Fe}_{2} \mathrm{O}_{3}$ in the melt/fluid affecting the rocks. This concerns not only the Reactions 3 and 6 presented above but plays a key role in the formation of unusual rim2' in megacrystalline harzburgite UV49/10 (Figure 2f). This rim develops, apparently, replacing usual rim2 under conditions of increased activity of the carbonated fluid enriched in the ferruginous component. This rim consists of phlogopite with a high proportion of tetraferriphlogopite, calcite, and serpentine:

$$
\begin{gathered}
\mathrm{KMg}_{3} \mathrm{AlSi}_{3} \mathrm{O}_{10}(\mathrm{OH})_{2}(\mathrm{Phl})+7 \mathrm{CaMgSi}_{2} \mathrm{O}_{6}(\mathrm{Cpx})+6 \mathrm{MgSiO}_{3}(\mathrm{Opx})+\mathrm{MgAl}_{2} \mathrm{O}_{4}(\mathrm{Spl})+\left[7 \mathrm{MgCO} \mathrm{Cl}_{3}+4 \mathrm{Fe}^{2+} \mathrm{O}\right. \\
\left.+\mathrm{O}_{2}+3 \mathrm{~K}_{2} \mathrm{O}+8 \mathrm{H}_{2} \mathrm{O}\right](\text { melt } / \text { fluid }) \rightarrow \\
\left.+7 \mathrm{KMg}_{3} \mathrm{Fe}^{3+} \mathrm{Si}_{3} \mathrm{O}_{10}(\mathrm{OH})_{2} \cdot 6 \mathrm{KMg}_{3}\left(\mathrm{Al}_{3}, \mathrm{Fe}^{3+}\right) \mathrm{Si}_{3} \mathrm{O}_{10}(\mathrm{OH})_{2}\right\}(\mathrm{Fe}-\mathrm{Phl}) \\
+7 \mathrm{CaCO}_{3}(\mathrm{Cal})+\mathrm{Mg}_{3} \mathrm{Si}_{2} \mathrm{O}_{5}(\mathrm{OH})_{4}\left(\mathrm{Srp}_{2} .\right.
\end{gathered}
$$

Rims 1 and 2 of peridotite garnets and garnets of Ecl A and B often contains sodalite (Table 1, Figures $2 \mathrm{e}$ and $3 \mathrm{~b}, \mathrm{f}$ ). An unidentified chlorine-containing magnesium aluminosilicate was found in rim2 surrounding garnets in MHD (see the section Classification). In general, these minerals are secondary and fill the space between grains of pyroxene, spinel, and plagioclase in rim1 (Figure 3b). In rim2, they rarely occur in interstices (* in Figure 2e); more often they form plates and are found in intergrowths with the main minerals of the rim (sodalite in Figures 2e and 3f; * in Figure 2c). It is difficult to imagine the reactions of rim formation with the participation of the above minerals, reflecting all the nuances of the process. Therefore, I will confine myself to the remark that the finds of such minerals in two types of rims indicate a prolonged period of activity in the fluid/melt of not only $\mathrm{Na}$ but also $\mathrm{Cl}$.

The position, mineral composition, and chemistry of the rim 3 minerals suggest that this rim replaces rims 1and 2 during the capture of xenolith by aggressive kimberlite melt and the rise of the rock to the surface. As noted above (see the description of rim3), this rim is composed mainly of phlogopite, often containing $\mathrm{CaO}$ admixtures, which are apparently caused by micro-growths of calcite. Spinel of the rim, the number of grains of which sharply increases at the boundary with kimberlite, contains a magnesioferrite/magnetite $\left(\mathrm{Fe}^{3+}\right)$ molecule instead of a hercynite $\left(\mathrm{Fe}^{2+}\right)$ in rim2 (see Reaction 3), which suggests oxidation during the formation of rim3. The ulvöspinel component increases in the spinel of this rim (Table 2). In general, the reaction of the process can be written as follows:

$$
\begin{aligned}
& \left\{7 \mathrm{Mg}_{2} \mathrm{Si}_{2} \mathrm{O}_{6} \cdot \mathrm{MgAl}_{2} \mathrm{SiO}_{6}\right\}(\mathrm{Opx} 1,2)+\left\{7 \mathrm{CaMgSi}_{2} \mathrm{O}_{6} \cdot \mathrm{MgAl}_{2} \mathrm{SiO}_{6}\right\}(\mathrm{Cpx} 1,2)+\left\{\mathrm{MgAl}_{2} \mathrm{O}_{4} \cdot 2 \mathrm{FeAl}_{2} \mathrm{O}_{4}\right\}(\mathrm{Spl} 1,2) \\
& +\mathrm{KMg}_{3} \mathrm{AlSi}_{3} \mathrm{O}_{10}(\mathrm{OH})_{2}(\mathrm{Phl1}, 2)+\left[2 \mathrm{TiO}_{2}+23 \mathrm{FeO}_{2}+2.5 \mathrm{O}_{2}+5 \mathrm{~K}_{2} \mathrm{O}+10 \mathrm{H}_{2} \mathrm{O}+7 \mathrm{CO}_{2}\right]\left(\mathrm{kimberlite} \mathrm{melt}^{2}\right) \\
& \quad \rightarrow 11 \mathrm{KMg}_{2} \mathrm{FeAli}_{3} \mathrm{O}_{10}(\mathrm{OH})_{2}(\mathrm{Phl} 3)+\left\{5 \mathrm{MgFe}_{2} \mathrm{O}_{4}(\mathrm{Mfr}) \cdot 2 \mathrm{Fe}_{2} \mathrm{TiO}_{4}(\mathrm{Usp})\right\}(\mathrm{Spl} 3)+7 \mathrm{CaCO}_{3} \text { (Cal). }
\end{aligned}
$$


The mineral assemblages in rims 1,2, and 3 surrounding garnets of Ecl A and some $\mathrm{Ecl} \mathrm{B}$ are the same as their counterparts from peridotites samples (Table 1) and could be described as reactions that are analogous to those above. Plagioclase is usually present in the kelyphite rims of some Ecl B and all studied Ecl C instead of phlogopite. The total chemical composition of the rim differs insignificantly from that of garnet. In the case of the presence of amphibole in the rim, there may be an admixture of sodium and a deficiency of the sum compared to that in garnet. The reaction of the formation of a typical (amphibole-free) Ecl C rim is shown below; the grossular molecule in the composition of studied garnets is $41-47 \%$. The process is the isochemical decomposition of the garnet:

$$
\begin{gathered}
4 \mathrm{Ca}_{1.25} \mathrm{Mg}_{1.75} \mathrm{Al}_{2} \mathrm{Si}_{3} \mathrm{O}_{12}(\mathrm{Grt}) \rightarrow 2\left\{2 \mathrm{CaMgSi} \mathrm{O}_{6} \cdot \mathrm{MgAl}_{2} \mathrm{SiO}_{6}\right\}(\mathrm{Cpx})+\mathrm{MgAl}_{2} \mathrm{O}_{4}(\mathrm{Spl})+\mathrm{CaAl}_{2} \mathrm{Si}_{2} \mathrm{O}_{8}(\mathrm{Pl}), \\
\text { where } \mathrm{Al}=\mathrm{Al}+\mathrm{Cr} ; \mathrm{Mg}=\mathrm{Mg}+\mathrm{Fe} \text {. } \\
\mathrm{Rim} 4 \text { consists of zonal abnormally high-chromium phlogopite, often with small grains } \\
\text { of chromium spinel at the edge (Figure } 1 \mathrm{i}) \text { and surrounds high-chromium subcalcium } \\
\text { MHD garnets. The process develops according to the following scheme: } \\
\qquad \mathrm{Mg}_{3} \mathrm{Cr}_{2} \mathrm{Si}_{3} \mathrm{O}_{12}(\mathrm{Grt})+\left[0.5 \mathrm{MgO}+\mathrm{H}_{2} \mathrm{O}+0.5 \mathrm{~K}_{2} \mathrm{O}\right](\text { melt } / \mathrm{fluid}) \\
\rightarrow \mathrm{KMg}_{3} \mathrm{CrSi}_{3} \mathrm{O}_{10}(\mathrm{OH})_{2}(\mathrm{Phl})+0.5 \mathrm{MgCr}_{2} \mathrm{O}_{4}(\mathrm{Spl})
\end{gathered}
$$

The unusual chromium content of phlogopites from rim4 is due to the high content of this component in MHD garnets and can be explained by the highly reducing conditions of rim formation or by chromite micro-ingrowths, which, however, were not detected during the high-resolution SEM studies.

The variability of mineral associations of Rim 5 makes it meaningless to write any reactions of the formation of this rim. Its composition indicates the enrichment of the system with calcium, potassium, and water.

The presence of phlogopite in almost all rim types indicates repeated $\mathrm{K}$ and $\mathrm{H}_{2} \mathrm{O}$ in-puts into the system. Phlogopites of different generations and compositions formed depending on the state of the system (Table 2). This confirms the important role of phlogopite in upper mantle metasomatism [47].

The emergence of the same types of kelyphite rims on garnets from three different mantle parageneses indicates that the rims shared the same prerequisites for their formation, although the details of the process could be different based on the initial parameters of the system.

\subsection{PT Parameters of Phase Equilibrium in Rims}

It is pertinent to compare the equilibrium pressures and temperatures of kelyphite rims forming with the respective parameters for the host xenoliths. Of all of the analyzed paragenetic types, only mineral assemblages in ShP are composed of four minerals, which allows one to freely operate with the equations from the PT database and, therefore, determine their PT parameters with good accuracy. The determination of the respective parameters for MHD and eclogites is always fraught with difficulties arising from the scarcity of the mineral composition of these parageneses. The superimposed metasomatic processes can strongly influence the calculations and provide a distorted picture; for instance, with temperature projections on the mantle geotherm. Metasomatism is the principal cause of the rim formation. Rims of all types, except rim3, form under the effect of metasomatic agents prior to the entrapment of xenoliths by kimberlite magma [31,42,48].

The determination of the PT parameters of rim formation begins with reconstructing the crystallization sequence in the rims. Given that ortho- and clinopyroxene form concurrently (see the reactions above), their equilibrium pressure and temperature can be estimated using known thermobarometers. The equilibrium of ortho- and clinopyroxenes in a lherzolite system can be tested using the $\mathrm{Ca}$ in cpx-Ca in the opx model suggested by [49]. This model was later modified [50] by adding composition trends from experiments [51]. As shown in Figure 6a, fields of equilibrium compositions (points of 
nonequilibrium compositions are not shown) of two pyroxenes in peridotite and eclogite rims are significantly overcovered. According to such a preliminary assessment, the peridotite rims formed in a wider pressure and temperature range than the eclogite rims.

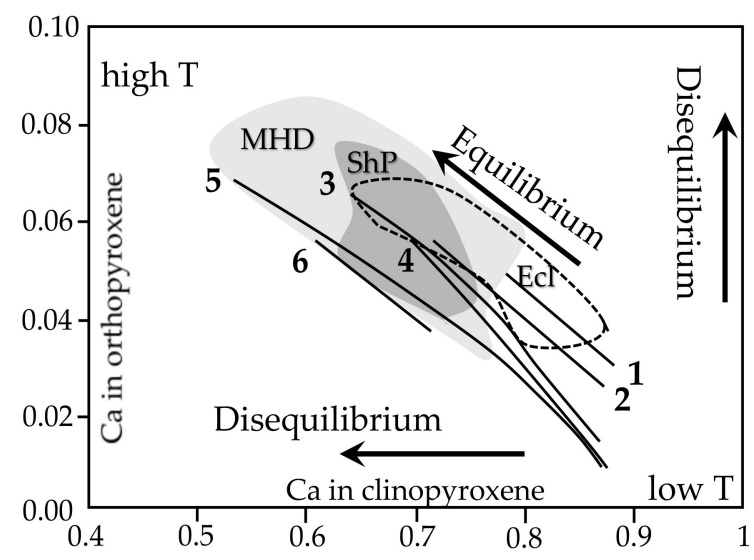

(a)

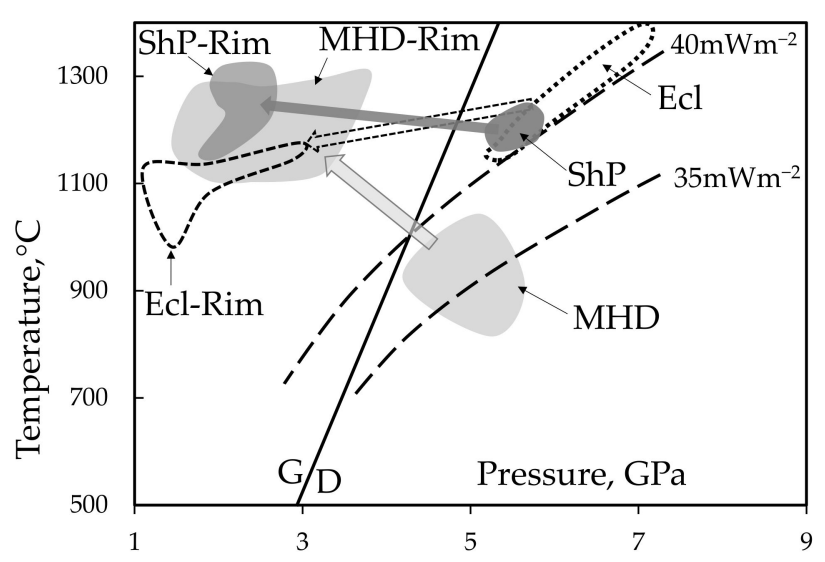

(b)

Figure 6. PT parameters of $\mathrm{MHD}, \mathrm{ShP}$, and Ecl kelyphite rims 1-2: (a) Fields of equilibrium pyroxene pairs in the rims surrounding studied xenoliths garnets in the diagram $\mathrm{Ca}$ in orthopyroxene versus $\mathrm{Ca}$ in coexisting clinopyroxene based on six oxygens per formula unit [50]. Lines 1-6 show the equilibria in the experimental system at temperatures of $900-1400{ }^{\circ} \mathrm{C}$ and pressures of 1-6 GPa [51]; (b) PT for the kelyphites calculated using geothermometers BK90 [52] and geobarometers MG74 [53], FB87 [54]; P-T parameters of the studied peridotites were calculated according to [55,56], data for eclogites were taken from [31]; the solid line GD separates the stability fields of graphite and diamond [57]; dotted lines-mantle geotherms 40 and $35 \mathrm{mwm}^{-2}$ [58].

The main problem of PT calculations for the pyroxene pairs from the analyzed rims is that the pyroxenes result from reactions of garnet breakdown and are not equilibrated with olivine as required using suitable thermobarometers [51-54]. Therefore, results of PT calculations shown in Figure $6 \mathrm{~b}$ are only tentative. The temperature for equilibrium pyroxene pairs from rims was calculated following [52], and the pressure was estimated using $\mathrm{Al}_{2} \mathrm{O}_{3}$ isopleths from [53] and the equation from [54]. Similar parameters of the formation of kelyphite rims are given in [20,59-61].

Proceeding from the obtained data, the rims surrounding mantle garnets may be inferred to form at the heating of rocks and/or decompression, according to the reactions cited above. This mainly occurs during the cracking of mantle areas as a result of movements in preparation for the eruption of kimberlite magma. Aggressive (asthenospheric?) melts/fluids percolate along formed cracks and produce new mineral assemblages in interstices, e.g., [28] microcracks, zoning in garnet composition [26,62], kelyphite rims, and zones of pyroxene alteration $[28,63,64]$. Local metasomatic changes of rocks, specific for certain mantle sections, including the formation of unusual rims, can occur in intermediate magmatic chambers [60].

\subsection{Geochemistry of Rim1/2, 3}

Figure 7 shows the average REE values of kelyphite rims and their host garnets of different parageneses. PM-normalized rim1/2 REE patterns of MHD, ShP, and Ecl have shapes similar to those of their garnets on segments of MREE and HREE but demonstrate remarkable enrichment in LREE. The identical enrichment character of such kelyphite rims on garnets of three different parageneses suggests a single source of enrichment (as an option, deep metasomatic fluid/melt). At the same time, rim3 of two garnets belonging to different peridotite parageneses (depleted and enriched) has a distribution pattern similar to that of the kimberlite of the Udachnaya pipe [33]. This is direct evidence of the conjugation of the formation of this type of rim with kimberlite magmatism. Measurements in the K-Ar system give both kimberlitic and more ancient ages compared to kimberlite 
for kelyphitic rims on peridotite garnets [48], confirming the previously noted influence of different agents in the formation of different kelyphite types [16,21].

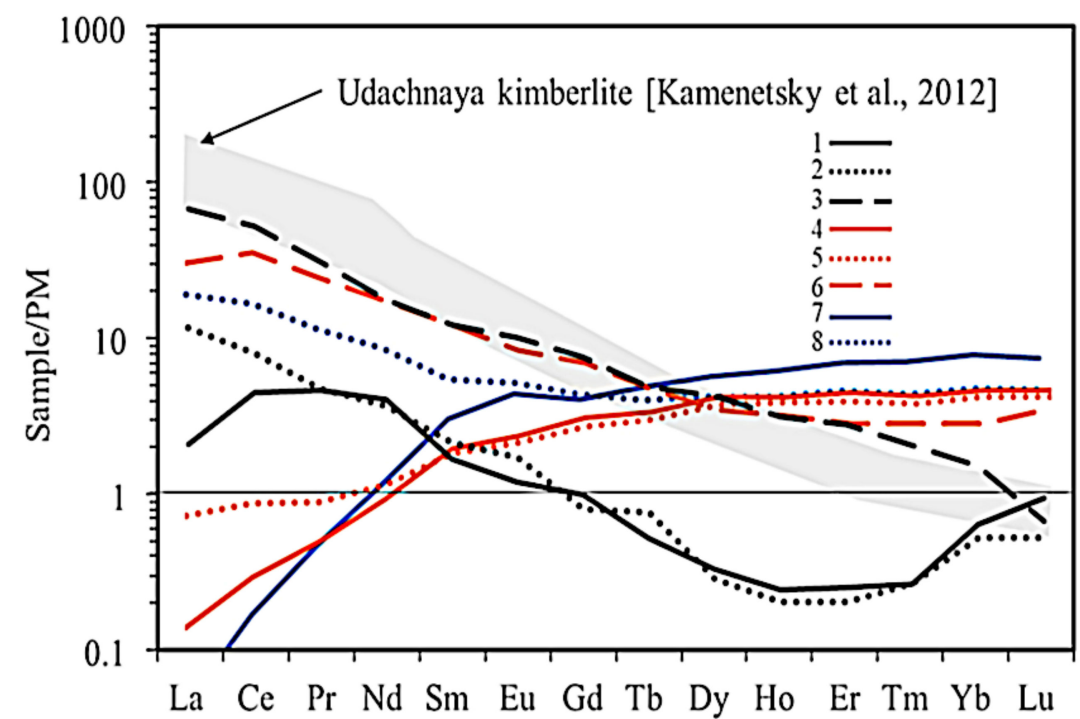

Figure 7. Primitive mantle normalized (after [45]) values of REE patterns of garnets and kelyphites from MHD, ShP, and Ecl xenoliths and REE distribution for the Udachnaya kimberlites. 1-MHD Grt (this study; average from seven samples: UV49/10, UV71/10, UV667/11, UV26/10-1, UV12/01-1, UV134/09, UV159/10-2); 2-MHD rim1/2 (this study; average from six samples: UV49/10, UV71/10, UV667/11, UV26/10-1, UV12/01-1, UV134/09); 3-MHD rim3 (this study; one sample: UV159/10-2); 4-ShP Grt (this study; average from five samples: UV831/09, UV71/09, UV163/09, UV862/09, UV207/09); 5-ShP rim1/2 (this study; average from four samples: UV831/09, UV71/09, UV163/09, UV862/09); 6-ShP rim3 (this study; one sample: UV207/09); 7—Ecl Grt ([31]; average from fourteen samples); 8-Ecl rim1/2 ([30]; average from the same fourteen samples).

\section{Conclusions}

The reported results lead to several important inferences:

1. Garnets from different parageneses are surrounded by similar kelyphite rims of several types. Rims on garnets from MHD, ShP, and Ecl A and B samples are composed of the same main minerals.

2. Garnets from the most depleted samples (MHD) have the most diverse rim types.

3. Small sizes $(\mu \mathrm{m})$ of mineral grains in rims, their zoning, and lack of equilibrium, idicate a high rate of formation. Variations in the compositions of minerals with the same name, and the variety of formation reactions with a change in the redox situation in some of these, attest to the multi-stage formation of kelyphite rims and the inversion of the fluid regime within small mantle areas.

4. Rims 1 and 2 formed before the intrusion of kimberlite in the conditions of the active migration of alkali- and water-rich metasomatic fluids along cracks in mantle rocks. The presence of sodalite and an unidentified $\mathrm{Cl}$-bearing silicate phase in rims of this type indicates the participation of chlorine during their formation.

5. Rim4 formed at higher activity of $\mathrm{K}$ and water. The high chromium content indicates on the effect of the reduced fluid.

6. Rim3 formed when kimberlites entrapped xenoliths.

7. The origin of rim5 ("pockets" in rim1) remains unclear. These rims can represent zones of local carbonatization at the reaction front, which is consistent with inference (3).

8. Each type of kelyphite demonstrates a clear enrichment with a certain component: Rim1- $\mathrm{MgO}$ and alkalis; $\mathrm{rim} 2-\mathrm{TiO}_{2} ; \mathrm{rim} 3-\mathrm{FeO}$ and $\mathrm{TiO}_{2} ; \mathrm{rim} 4-\mathrm{Cr}_{2} \mathrm{O}_{3}$; and rim5- $\mathrm{Ca} 0$, suggesting the stage-by-stage metasomatic enrichment of upper mantle rocks. 
Funding: This research was funded by the Russian Foundation for Fundamental Investigations, grant numbers 18-05-70063 and 20-05-00662, and was undertaken on state assignment of IGM SB RAS.

Data Availability Statement: The data presented in this article was obtained by author in the course of this study.

Acknowledgments: All analytical work was performed at the Analytical Center for multi-elemental and isotope re-search, SB RAS. The author is sincerely grateful to the staff of the Analytical CenterSenior Researcher, Korolyuk V.N.; Senior Researcher, Karmanov N.S.; and Khlestov M.V.-for invaluable assistance in obtaining reliable and high-quality analyses of the studied minerals. I would like to express special gratitude to S.I. Kostrovitsky and M. Obata, whose advice and comments helped me consider clearer wording, changing or adding illustrative material, and revising the structure of the presentation of this article. I also thank the MDPI Reviewers and Academic Editors for their attention to my research.

Conflicts of Interest: The author declares no conflict of interest.

\section{Appendix A}

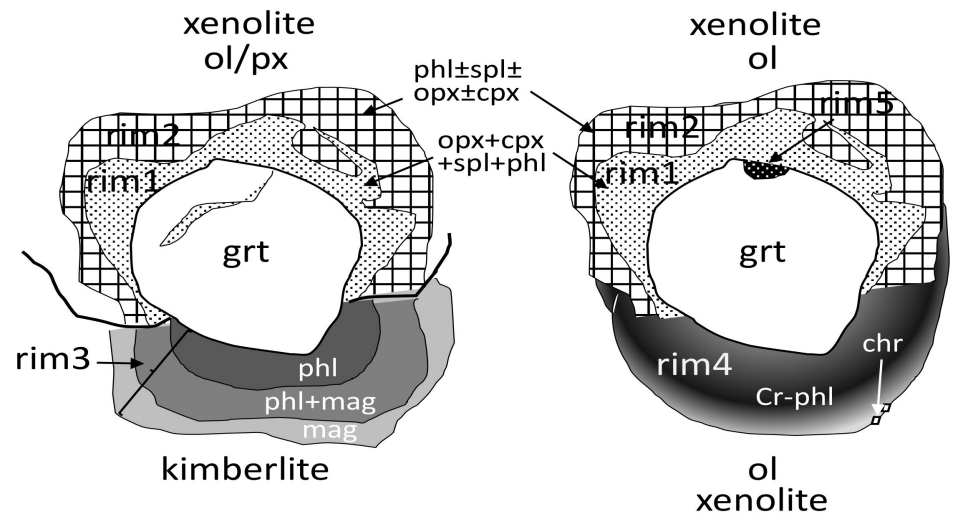

(a)

(b)

Figure A1. Scheme of the kelyphite rim types, locations, and compositions: (a) Rims 1, 2 and 3 surrounding garnets of peridotites or eclogites A, B; (b) rims 4 and 5 surrounding garnets of MHD.

\section{Appendix B}

The appendix contains three Tables with chemical compositions data of the studied garnets and rims. 
Table A1. Chemical compositions (wt.\%) of MHD and ShP garnets in Udachnaya-East kimberlite pipe (Yakutia, Russia).

\begin{tabular}{|c|c|c|c|c|c|c|c|c|c|c|c|}
\hline Paragenesis & Sample & $\mathrm{SiO}_{2}$ & $\mathrm{TiO}_{2}$ & $\mathrm{Al}_{2} \mathrm{O}_{3}$ & $\mathrm{Cr}_{2} \mathrm{O}_{3}$ & $\mathrm{FeO}$ & $\mathrm{MnO}$ & $\mathrm{MgO}$ & $\mathrm{CaO}$ & $\mathrm{Na}_{2} \mathrm{O}$ & Total \\
\hline \multirow{32}{*}{ MHD } & UV2/09 & 41.17 & 0.083 & 14.63 & 11.12 & 6.803 & 0.455 & 20.82 & 4.450 & 0.031 & 99.57 \\
\hline & UV12/01-1 & 41.36 & 0.000 & 16.55 & 8.540 & 7.186 & 0.376 & 21.9 & 3.377 & 0.012 & 99.30 \\
\hline & UV26/10-1 & 41.67 & 0.002 & 16.22 & 8.894 & 6.906 & 0.403 & 22.64 & 2.351 & 0.015 & 99.12 \\
\hline & UV49/10 & 41.79 & 0.017 & 16.73 & 9.309 & 6.592 & 0.432 & 23.65 & 1.227 & 0.030 & 99.79 \\
\hline & UV70/01 & 41.79 & 0.044 & 16.35 & 9.418 & 6.673 & 0.351 & 22.83 & 1.754 & 0.042 & 99.27 \\
\hline & UV71/10 & 41.24 & 0.036 & 15.41 & 10.76 & 6.911 & 0.363 & 22.75 & 1.643 & 0.00 & 99.12 \\
\hline & UV112/09 & 41.59 & 0.411 & 18.43 & 5.664 & 7.277 & 0.358 & 20.71 & 4.537 & 0.122 & 99.12 \\
\hline & UV113/09 & 41.65 & 0.000 & 16.65 & 9.322 & 6.275 & 0.342 & 22.93 & 2.507 & 0.040 & 99.72 \\
\hline & UV134/09 & 41.11 & 0.052 & 15.96 & 9.838 & 6.569 & 0.354 & 23.39 & 2.176 & 0.039 & 99.51 \\
\hline & UV157/10-2 & 40.96 & 0.003 & 14.31 & 11.85 & 7.017 & 0.434 & 23.35 & 1.682 & 0.056 & 99.67 \\
\hline & UV159/10-1 & 41.6 & 0.033 & 16.14 & 9.206 & 6.684 & 0.438 & 22.8 & 2.041 & 0.052 & 99.01 \\
\hline & UV159/10-2 & 41.02 & 0.033 & 15.07 & 10.58 & 6.927 & 0.416 & 19.99 & 5.485 & 0.021 & 99.55 \\
\hline & UV162/10-1 & 40.09 & 0.119 & 13.13 & 13.13 & 6.903 & 0.439 & 18.92 & 6.536 & 0.054 & 99.32 \\
\hline & UV162/10-2 & 41.44 & 0.007 & 16.02 & 9.924 & 6.994 & 0.35 & 22.72 & 2.252 & 0.003 & 99.71 \\
\hline & UV167/09 & 41.05 & 0.000 & 15.04 & 11.10 & 6.856 & 0.363 & 23.45 & 2.131 & 0.012 & 100.0 \\
\hline & UV177/09 & 40.55 & 0.441 & 14.68 & 9.680 & 7.015 & 0.263 & 20.3 & 6.384 & 0.032 & 99.36 \\
\hline & UV233/10 & 40.32 & 0.091 & 14.84 & 10.72 & 6.900 & 0.393 & 20.98 & 4.788 & 0.070 & 99.09 \\
\hline & UV343/08 & 40.74 & 0.016 & 14.56 & 11.47 & 7.281 & 0.410 & 22.01 & 3.375 & 0.065 & 99.94 \\
\hline & UV517/11 & 41.14 & 0.171 & 15.20 & 10.18 & 6.561 & 0.371 & 20.72 & 4.677 & 0.052 & 99.09 \\
\hline & UV524/11 & 40.51 & 0.073 & 14.41 & 11.67 & 6.785 & 0.400 & 19.82 & 4.890 & 0.043 & 98.60 \\
\hline & UV528/11 & 40.33 & 0.007 & 16.06 & 9.688 & 7.139 & 0.437 & 21.97 & 3.496 & 0.033 & 99.17 \\
\hline & UV586/11 & 41.16 & 0.113 & 15.80 & 9.992 & 7.212 & 0.394 & 21.26 & 3.697 & 0.052 & 99.67 \\
\hline & UV588/11 & 40.79 & 0.021 & 15.25 & 10.56 & 7.010 & 0.423 & 22.36 & 2.859 & 0.018 & 99.29 \\
\hline & UV658/11 & 41.37 & 0.043 & 16.42 & 8.719 & 7.000 & 0.413 & 20.77 & 4.579 & 0.002 & 99.33 \\
\hline & UV667/11 & 41.08 & 0.061 & 15.13 & 10.88 & 6.96 & 0.401 & 21.37 & 3.540 & 0.000 & 99.43 \\
\hline & UV708/11 & 41.11 & 0.090 & 15.35 & 10.04 & 6.478 & 0.32 & 22.78 & 3.123 & 0.040 & 99.36 \\
\hline & UV803/09 & 40.79 & 0.078 & 14.19 & 12.2 & 7.182 & 0.408 & 21.04 & 3.797 & 0.020 & 99.70 \\
\hline & UV818/09 & 41.14 & 0.135 & 15.94 & 9.754 & 7.061 & 0.415 & 21.12 & 3.612 & 0.077 & 99.26 \\
\hline & UV823/09 & 41.17 & 0.019 & 16.44 & 9.285 & 6.868 & 0.416 & 23.51 & 1.793 & 0.000 & 99.50 \\
\hline & UV833/09 & 40.64 & 0.050 & 15.70 & 10.72 & 6.980 & 0.36 & 20.36 & 5.000 & 0.030 & 99.88 \\
\hline & UV837/11 & 40.74 & 0.769 & 14.83 & 8.675 & 6.846 & 0.311 & 21.03 & 6.083 & 0.073 & 99.37 \\
\hline & UV850/09 & 41.32 & 0.089 & 15.78 & 9.956 & 6.385 & 0.324 & 22.26 & 3.002 & 0.048 & 99.18 \\
\hline \multirow{5}{*}{ ShP } & UV831/09 & 42.55 & 0.520 & 20.99 & 1.910 & 7.870 & 0.000 & 21.77 & 4.390 & 0.000 & 100.0 \\
\hline & UV71/09 & 41.49 & 1.273 & 16.41 & 6.422 & 8.503 & 0.289 & 20.01 & 5.201 & 0.116 & 99.72 \\
\hline & UV163/09 & 40.76 & 1.466 & 14.18 & 9.064 & 8.057 & 0.367 & 19.23 & 6.358 & 0.106 & 99.61 \\
\hline & UV862/09 & 41.58 & 0.959 & 18.24 & 4.581 & 7.942 & 0.292 & 20.96 & 5.292 & 0.113 & 99.98 \\
\hline & UV207/10 & 40.54 & 0.820 & 14.89 & 9.500 & 7.140 & 0.350 & 19.60 & 6.350 & 0.000 & 99.19 \\
\hline
\end{tabular}

Table A2. Rare-earth composition (in ppm) of MHD and ShP garnets of Udachnaya-East kimberlite pipe (Yakutia, Russia).

\begin{tabular}{|c|c|c|c|c|c|c|c|c|c|c|c|c|c|c|c|}
\hline Paragenesis & Sample & La & $\mathrm{Ce}$ & Pr & Nd & Sm & $\mathbf{E u}$ & Gd & $\mathrm{Tb}$ & Dy & Ho & Er & $\mathrm{Tm}$ & $\mathbf{Y b}$ & Lu \\
\hline \multirow{32}{*}{ MHD } & UV2/09 & 0.370 & 2.859 & 0.543 & 3.037 & 0.754 & 0.231 & 0.812 & 0.063 & 0.304 & 0.076 & 0.250 & 0.034 & 0.017 & \\
\hline & UV12/01-1 & 0.303 & 4.293 & 1.149 & 8.144 & 0.869 & 0.246 & 0.418 & 0.027 & 0.155 & 0.044 & 0.168 & 0.036 & 0.523 & 0.186 \\
\hline & UV26/10-1 & 0.128 & 2.170 & 0.643 & 4.265 & 0.612 & 0.131 & 0.532 & 0.002 & 0.195 & 0.012 & 0.008 & & 0.007 & 0.032 \\
\hline & UV49/10 & 1.091 & 9.535 & 1.087 & 4.258 & 0.376 & 0.131 & 0.447 & 0.034 & 0.197 & 0.028 & 0.033 & 0.005 & 0.292 & 0.049 \\
\hline & UV70/01 & 0.587 & 6.138 & 0.839 & 4.141 & 0.75 & 0.151 & 0.461 & 0.066 & 0.110 & 0.027 & 0.074 & 0.003 & 0.252 & 0.041 \\
\hline & UV71/10 & 2.220 & 4.882 & 0.512 & 2.616 & 0.321 & 0.101 & 0.376 & 0.079 & 0.149 & 0.031 & 0.171 & 0.021 & 0.213 & 0.057 \\
\hline & UV112/09 & 0.035 & 0.249 & 0.119 & 1.902 & 1.005 & 0.509 & 1.26 & 0.199 & 1.174 & 0.143 & 0.594 & 0.171 & 1.206 & 0.249 \\
\hline & UV113/09 & 0.491 & 6.793 & 1.839 & 12.88 & 3.634 & 0.978 & 2.161 & 0.162 & 0.612 & 0.112 & 0.219 & 0.028 & 0.181 & 0.027 \\
\hline & UV134/09 & 0.482 & 4.648 & 0.986 & 3.954 & 0.817 & 0.219 & 0.337 & 0.041 & 0.148 & 0.036 & 0.106 & 0.032 & 0.32 & 0.075 \\
\hline & UV157/10-2 & 0.851 & 7.82 & 1.461 & 8.406 & 0.703 & 0.128 & 0.461 & & 0.105 & 0.05 & 0.107 & 0.033 & 0.327 & 0.059 \\
\hline & UV159/10-1 & 0.928 & 14.56 & 3.859 & 22.73 & 3.55 & 0.842 & 1.606 & 0.154 & 0.515 & 0.126 & 0.283 & 0.041 & 0.509 & 0.131 \\
\hline & UV159/10-2 & 1.245 & 7.679 & 1.454 & 8.59 & 1.238 & 0.181 & 0.826 & 0.085 & 0.319 & 0.068 & 0.286 & 0.031 & 0.815 & 0.067 \\
\hline & UV162/10-1 & 0.468 & 1.693 & 0.303 & 1.499 & 0.283 & 0.122 & 0.527 & 0.081 & 0.507 & 0.149 & 0.575 & 0.075 & 1.096 & 0.208 \\
\hline & UV162/10-2 & 0.099 & 2.126 & 0.675 & 5.256 & 0.756 & 0.179 & 0.283 & 0.003 & 0.015 & 0.003 & 0.112 & 0.034 & 0.286 & 0.066 \\
\hline & UV167/09 & 0.741 & 4.695 & 0.829 & 2.297 & 0.202 & 0.048 & 0.163 & 0.02 & 0.067 & 0.016 & 0.056 & 0.019 & 0.132 & 0.005 \\
\hline & UV177/09 & 0.490 & 2.187 & 0.446 & 4.235 & 1.876 & 0.532 & 1.121 & 0.033 & 0.289 & 0.093 & 0.285 & 0.044 & 0.547 & 0.159 \\
\hline & UV233/10 & 0.133 & 1.919 & 0.529 & 3.534 & 2.672 & 0.823 & 1.828 & 0.136 & 0.152 & 0.044 & 0.027 & 0.014 & 0.127 & 0.199 \\
\hline & UV343/08 & 0.535 & 4.069 & 1.058 & 9.185 & 2.002 & 0.334 & 0.648 & 0.054 & 0.260 & 0.087 & 0.100 & 0.043 & 0.387 & 0.171 \\
\hline & UV517/11 & 0.347 & 4.683 & 1.284 & 8.685 & 2.666 & 0.86 & 2.599 & 0.310 & 1.563 & 0.210 & 0.600 & 0.085 & 0.725 & 0.023 \\
\hline & UV524/11 & 0.702 & 4.283 & 0.62 & 3.046 & 0.536 & 0.264 & 0.807 & 0.107 & 0.661 & 0.206 & 0.599 & 0.073 & 0.863 & 0.081 \\
\hline & UV528/11 & 1.256 & 12.469 & 2.734 & 15.283 & 2.255 & 0.324 & 0.822 & 0.026 & 0.275 & 0.106 & 0.290 & 0.057 & 0.667 & 0.117 \\
\hline & UV586/11 & 0.249 & 2.861 & 0.844 & 6.512 & 1.154 & 0.321 & 0.868 & 0.087 & 0.627 & 0.106 & 0.214 & 0.053 & 0.715 & 0.093 \\
\hline & UV588/11 & 0.761 & 8.799 & 2.074 & 10.39 & 1.214 & 0.238 & 0.529 & 0.037 & 0.213 & 0.045 & 0.116 & 0.02 & 0.436 & 0.234 \\
\hline & UV658/11 & 0.269 & 2.402 & 0.356 & 1.560 & 0.071 & 0.031 & 0.253 & 0.039 & 0.247 & 0.105 & 0.273 & 0.042 & 0.660 & 0.108 \\
\hline & UV667/11 & 1.844 & 14.39 & 2.459 & 11.68 & 1.496 & 0.285 & 0.755 & 0.051 & 0.302 & 0.133 & 0.346 & 0.049 & 0.597 & 0.096 \\
\hline & UV708/11 & 0.093 & 1.281 & 0.501 & 4.910 & 3.047 & 0.896 & 1.830 & 0.188 & 0.764 & 0.073 & 0.191 & 0.035 & 0.150 & 0.311 \\
\hline & UV803/09 & 1.911 & 5.423 & 0.357 & 1.441 & 0.35 & 0.104 & 0.444 & 0.047 & 0.416 & 0.138 & 0.531 & 0.081 & 0.950 & 0.141 \\
\hline & UV818/09 & 0.299 & 3.464 & 0.862 & 5.683 & 1.165 & 0.262 & 0.843 & 0.088 & 0.631 & 0.082 & 0.324 & 0.042 & 0.472 & 0.072 \\
\hline & UV823/09 & 0.152 & 1.305 & 0.196 & 1.359 & 0.434 & 0.037 & 0.129 & 0.014 & 0.098 & 0.011 & 0.032 & 0.026 & 0.253 & 0.256 \\
\hline & UV833/09 & 0.303 & 1.606 & 0.227 & 0.897 & 0.208 & 0.049 & 0.13 & 0.031 & 0.229 & 0.049 & 0.168 & 0.029 & 0.320 & 0.078 \\
\hline & UV837/11 & 0.190 & 2.170 & 0.669 & 6.254 & 1.407 & 0.468 & 0.762 & 0.120 & 0.654 & 0.009 & 0.054 & 0.315 & 1.919 & 0.098 \\
\hline & UV850/09 & 0.106 & 2.220 & 0.711 & 7.060 & 3.071 & 0.879 & 2.049 & 0.225 & 1.034 & 0.186 & 0.619 & 0.081 & 0.910 & 0.164 \\
\hline \multirow{5}{*}{ ShP } & UV831/09 & 0.093 & 0.476 & 0.116 & 0.986 & 0.614 & 0.298 & 1.501 & 0.296 & 2.584 & 0.593 & 1.932 & 0.308 & 2.050 & 0.345 \\
\hline & UV71/09 & 0.426 & 1.630 & 0.341 & 2.682 & 1.668 & 0.728 & 3.212 & 0.634 & 4.897 & 1.026 & 2.86 & 0.399 & 2.439 & 0.374 \\
\hline & UV163/09 & 0.127 & 1.190 & 0.321 & 2.978 & 1.891 & 0.835 & 3.413 & 0.615 & 4.212 & 0.805 & 2.157 & 0.276 & 1.665 & 0.249 \\
\hline & UV862/09 & 0.030 & 0.451 & 0.148 & 1.497 & 1.070 & 0.489 & 2.205 & 0.431 & 3.806 & 0.863 & 2.814 & 0.415 & 3.139 & 0.469 \\
\hline & UV207/10 & 0.119 & 0.927 & 0.265 & 2.172 & 1.061 & 0.403 & 1.308 & 0.174 & 0.946 & 0.146 & 0.325 & 0.045 & 0.309 & 0.057 \\
\hline
\end{tabular}


Table A3. Rare-earth composition (in ppm) of MHD and ShP garnet rims.

\begin{tabular}{|c|c|c|c|c|c|c|c|c|c|c|c|c|c|c|c|c|}
\hline Paragenesis & Sample & Rim & La & $\mathrm{Ce}$ & Pr & Nd & Sm & Eu & Gd & $\mathrm{Tb}$ & Dy & Ho & Er & $\operatorname{Tm}$ & $\mathbf{Y b}$ & Lu \\
\hline \multirow{7}{*}{ MHD } & UV49/10 & $1-2$ & 0.051 & 0.545 & 0.063 & 0.347 & 0.05 & 0.007 & & & & & & & 0.017 & 0.006 \\
\hline & UV $71 / 10$ & $1-2$ & 2.938 & 5.299 & 0.463 & 2.145 & 0.218 & 0.099 & 0.366 & 0.056 & 0.152 & 0.03 & 0.171 & 0.01 & 0.311 & 0.056 \\
\hline & UV667/11 & $1-2$ & 6.56 & 9.995 & 0.598 & 1.881 & 0.137 & 0.163 & 0.103 & & & & & & 0.005 & \\
\hline & UV26/10-1 & $1-2$ & 6.364 & 11.72 & 1.027 & 3.673 & 0.381 & 0.158 & 0.297 & 0.001 & 0.117 & 0.031 & 0.005 & & 0.118 & \\
\hline & UV12/01-1 & $1-2$ & 0.078 & 0.586 & 0.168 & 1.189 & 0.04 & 0.044 & 0.055 & & & & & & & \\
\hline & UV134/09 & $1-2$ & 0.549 & 1.076 & 0.079 & 0.142 & 0.131 & & & & & & & & 0.041 & \\
\hline & UV157/10-2 & 3 & 18.24 & 36 & 3.233 & 9.079 & 2.053 & 0.647 & 1.695 & 0.2 & 1.186 & 0.192 & 0.501 & 0.058 & 0.276 & 0.019 \\
\hline \multirow{5}{*}{ ShP } & UV831/09 & $1-2$ & 2.761 & 7.502 & 0.865 & 4.034 & 1.287 & 0.554 & 1.959 & 0.366 & 2.338 & 0.473 & 1.385 & 0.225 & 1.362 & 0.257 \\
\hline & UV71/09 & $1-2$ & 2.843 & 6.985 & 0.922 & 4.146 & 1.275 & 0.483 & 2.174 & 0.402 & 3.51 & 0.778 & 2.657 & 0.383 & 2.672 & 0.446 \\
\hline & UV163/09 & $1-2$ & 0.305 & 0.903 & 0.159 & 1.076 & 0.483 & 0.33 & 1.602 & 0.333 & 3.179 & 0.791 & 2.56 & 0.387 & 3.094 & 0.481 \\
\hline & UV862/09 & $1-2$ & 1.433 & 4.574 & 0.645 & 3.153 & 1.269 & 0.5 & 1.975 & 0.354 & 2.84 & 0.663 & 1.92 & 0.278 & 2.148 & 0.294 \\
\hline & UV207/10 & 3 & 23.61 & 70.26 & 7.44 & 26.88 & 6.193 & 1.652 & 4.907 & 0.618 & 3.153 & 0.643 & 1.697 & 0.261 & 1.699 & 0.319 \\
\hline
\end{tabular}

\section{References}

1. Müller, H. Geognostische Skizze der Greifendorfer Serpentin Partie. In Neues Jahrbuch für Mineralogie, Geognosie, Geologie und Petrefaktenkunde; Schweizerbarfscke Verlagshandlung und Druckerei: Stuttgart, Germany, 1846; pp. 257-288.

2. Delesse, A. Mémoire sur la constitution minéralogique et chimique des roches des Vosges. Serpentine des Vosges. Ann. Mines 1850, 18, 309-356.

3. Hochstetter, F. Geognostische Studien aus dem Böhmerwalde. Jahrb. K. K. Geol. Reichsanst. 1854, 5, 1-67.

4. Schrauf, A. Beiträge zur Kenntniss des Associations Kreises der Magnesia Silicate. Z. Krist. Miner. 1882, 6, 321-388.

5. Hezner, L. Ein Beitrag zur Kenntnis der Eklogite und Amphibolite mit besonderer Berücksichtigung der Vorkommnisse des mittleren Oetztals. Tschermaks Miner. Petrogr. Mitt. 1903, 2, 437-471.

6. Godard, G.; Martin, S. Petrogenesis of kelyphites in garnet peridotites: A case study from the Ulten zone, Italian Alps. J. Geodyn. 2000, 30, 117-145. [CrossRef]

7. Obata, M. Kelyphite and symplectite: Textural and mineralogical diversities and universality, and a new dynamic view of their structural formation. In New Frontiers in Tectonic Research-General Problems, Sedimentary Basins and Island Arcs; Sharkov, E., Ed.; InTech: London, UK, 2011; ISBN 978-953-307-595-2. Available online: http://www.intechopen.com/books/newfrontiers-in-tectonic-research-general-problems-sedimentarybasins-and-island-arcs/kelyphite-and-symplectite-textural-andmineralogical-diversities-and-universality-and-anew-dynamic1 (accessed on 4 June 2021). [CrossRef]

8. Obata, M. Material transfer and local equilibria in a zoned kelyphite from a garnet pyroxenite, Ronda, Spain. J. Petrol. 1994, 35, 271-287. [CrossRef]

9. Altherr, R.; Kalt, A. Metamorphic evolution of ultrahigh-pressure garnet peridotite from the Variscan Vosges Mts. (France). Chem. Geol. 1996, 134, 27-47. [CrossRef]

10. Dégi, J.; Abart, R.; Kalman, T.; Bali, E.; Wirth, R.; Rhede, D. Symplectite formation during decompression induced garnet breakdown in lower crustal mafic granulite xenoliths: Mechanisms and rates. Contrib. Mineral. Petrol. 2010, 159, 293-314. [CrossRef]

11. Zang, Q.; Enami, M.; Suwa, K. Aluminian orthopyroxene in pyrometamorphosed garnet megacryst from Liaoning and Shandong provinces, northeast China. Eur. J. Mineral. 1993, 5, 153-164. [CrossRef]

12. Fermor, L.L. Preliminary note on the origin of meteorites. J. Proc. Asiat. Soc. Bengal 1912, 8, 315-324.

13. Sobolev, N.V.; Lodocnikova, V.S. Mineralogy of garnet peridotites. Rus. Geol. Geophys. 1962, 6, 52-59. (In Russian)

14. Fediukova, E. Kelyphitic reaction rims in garnet peridotites. Acta Univ. Carol. Geol. 1979, 3-4, 185-192.

15. Fiala, Y.; Padera, K. The chemistry of the minerals of the pyrope dunite from Borehole T-7 near Stare (Bohemia). TMPM 1977, 24, 205-219. [CrossRef]

16. Kharkiv, A.D.; Vishnevsky, A.A. Features of garnet kellitization from xenoliths of deep rocks in kimberlites. Zap. Vsesoyuznogo Mineral. Obs. 1989, 118, 27-37. (In Russian)

17. Dawson, Y.B.; Smith, I.V. Occurense of diamond in a micagarnet lhersolite xenoliths from kimberlite. Nature 1975, 5501, 580-581. [CrossRef]

18. Treneva, N.V.; Vasilieva, G.L.; Ilupin, I.P. New data on garnets and keliphite rims from kimberlites of Yakutia. Dokl. Earth Sci. 1979, 247, 1471-1474. (In Russian)

19. Spetsius, Z.V.; Griffin, W.L. Trace element composition of garnet kelyphites in xenoliths from Udachnaya as evidence of their origin. In Proceedings of the 7th International Kimberlite Conference, Cape Town, South Africa, 13-17 April 1998; Red Roof Design: Cape Town, South Africa, 1999; Volume 7, pp. 853-855.

20. Foley, S.F.; Andronikov, A.V.; Jacob, D.E.; Melzer, S. Evidence from Antarctic mantle peridotite xenoliths for changes in mineralogy, geochemistry and geothermal gradients beneath a developing rift. Geochim. Cosmochim. Acta 2006, 70, 3096-3120. [CrossRef]

21. Ilupin, I.P.; Levshov, P.P.; Rovsha, V.S. On the composition and genesis of kelyphite shells on garnet-pyrope in kimberlites of Yakutia. Uchenye Zap. Nauchno Issledovatelskogo Inst. Geol. Arktiki. Reg. Geol. 1969, 16, 45-52. (In Russian)

22. Fiala, J. The distribution of elements in mineral phases of some garnet peridotites from the Bohemian massif. Krystalinikum 1966, 4, 31-53.

23. Van der Wal, D.; Vissers, R.L.M. Structural petrology of the Ronda peridotite, SW Spain: Deformation history. J. Petrol. 1996, 37, 23-43. [CrossRef] 
24. Pokhilenko, N.P.; Sobolev, N.V.; Boyd, F.R.; Pearson, D.G.; Shimizu, N. Megacrystalline pyrope peridotites in the lithosphere of the Siberian Platform: Mineralogy, geochemical peculiarities and the problem of their origin. Rus. Geol. Geophys. 1993, 34, 1-84.

25. Pokhilenko, L.N.; Malkovets, V.G.; Kuzmin, D.V.; Pokhilenko, N.P. New Data on the Mineralogy of Megacrystalline Pyrope Peridotite from the Udachnaya Kimberlite Pipe, Siberian Craton, Yakutian Diamondiferous Province. Dokl. Earth Sci. 2014, 454, 179-184. [CrossRef]

26. Howarth, G.H.; Barry, P.H.; Pernet-Fisher, J.F.; Baziotis, I.P.; Pokhilenko, N.P.; Pokhilenko, L.N.; Bodnar, R.J.; Taylor, L.A.; Agashev, A.M. Superplume metasomatism: Evidence from Siberian mantle xenoliths. Lithos 2014, 184-185, 209-224. [CrossRef]

27. Coleman, R.G.; Lee, D.E.; Beatty, L.B.; Brannock, W.W. Eclogites and eclogites: Their differences and similarities. Geol. Soc. Am. Bull. 1965, 76, 483-508. [CrossRef]

28. Taylor, L.A.; Neal, C.R. Eclogites with oceanic crustal and mantle signatures from the Bellsbank kimberlite, South Africa, part I: Mineralogy, petrography, and whole-rock chemistry. J. Geol. 1989, 97, 551-567. [CrossRef]

29. MacGregor, I.D.; Carter, J.L. The chemistry of clinopyroxenes and garnets of eclogite and peridotite xenoliths from the Roberts Victor mine, South Africa. Phys. Earth Planet Int. 1970, 3, 391-397. [CrossRef]

30. MaCandless, T.E.; Gurney, J.J. Sodium in garnet and potassium in clinopyroxene: Criteria for classifying mantle eclogites. In Kimberlite and Related Rocks: Proceedings of the Fourth International Kimberlite Conference (4 IKC), Perth, Australia, August 10-15 1986, Volume 2: Their Mantle/Crust Setting, Diamonds and Diamond Exploration; Geological Society of Australia Inc.: Hornsby, Australia, 1989; pp. 827-832.

31. Agashev, A.M.; Pokhilenko, L.N.; Pokhilenko, N.P.; Shchukina, E.V. Geochemistry of eclogite xenoliths from the Udachnaya Kimberlite Pipe: Section of ancient oceanic crust sampled. Lithos 2018, 314-315, 187-200. [CrossRef]

32. Kamenetsky, V.S.; Kamenetsky, M.B.; Sharygin, V.V.; Faure, K.; Golovin, A.V. Chloride and carbonate immiscible liquids at the closure of the kimberlite magma evolution (Udachnaya-East kimberlite, Siberia). Chem. Geol. 2007, 237, 384-400. [CrossRef]

33. Kamenetsky, V.S.; Kamenetsky, M.B.; Golovin, A.V.; Sharygin, V.V.; Maas, R. Ultrafresh salty kimberlite of the Udachnaya-East pipe (Yakutia, Russia): A petrological oddity or fortuitous discovery? Lithos 2012, 152, 173-186. [CrossRef]

34. Kamenetsky, V.S.; Golovin, A.V.; Maas, R.; Giuliani, A.; Kamenetsky, M.B.; Weiss, Y. Towards a new model for kimberlite petrogenesis: Evidence from unaltered kimberlites and mantle minerals. Earth Sci. Rev. 2014, 139, 145-167. [CrossRef]

35. Pokhilenko, L.N.; Golovin, A.V.; Sharygin, I.S.; Pokhilenko, N.P. Accessory Minerals of Mantle Xenoliths: First Finds of Cl-free K-Fe Sulfides. Dokl. Earth Sci. 2011, 440, 1404-1409. [CrossRef]

36. Sharygin, I.S.; Golovin, A.V.; Pokhilenko, N.P. Djerfisherite in Kimberlites of the Kuoikskoe field as an indicator of enrichment of Kimberlite melts in chlorine. Dokl. Earth Sci. 2011, 436, 301-307. [CrossRef]

37. Korolyuk, V.N.; Lavrent'ev, Y.G.; Usova, L.V.; Nigmatulina, E.N. JXA-8100 microanalyzer: Accuracy of analysis of rock-forming minerals. Rus. Geol. Geophys. 2008, 49, 165-168. [CrossRef]

38. Lavrentev, Y.G.; Karmanov, N.S.; Usova, L.V. Electron probe microanalysis of minerals: Microanalyzer or scanning electron microscope? Rus. Geol. Geophys. 2015, 56, 1154-1161. [CrossRef]

39. Norman, M.D.; Pearson, N.J.; Sharma, A.; Griffin, W.L. Quantitative Analysis of Trace Elements in Geological Materials by Laser Ablation ICPMS: Instrumental Operating Conditions and Calibration Values of NIST Glasses. Geostand. Newsl. 1996, $20,247-261$. [CrossRef]

40. Whitney, D.L.; Evans, B.W. Abbreviations for names of rock-forming minerals. Am. Mineral. 2010, 95, 185-187. [CrossRef]

41. Available online: https://www.mindat.org/min-52356.html (accessed on 4 June 2021).

42. Pokhilenko, L.N. Formation Sequence of Different Spinel Species in Megacrystalline Peridotites of the Udachnaya-East Kimberlite Pipe (Yakutia): Evidence for the Metasomatism of Depleted Mantle. Minerals 2019, 9, 607. [CrossRef]

43. Pokhilenko, N.P.; Agashev, A.M.; Litasov, K.D.; Pokhilenko, L.N. Carbonatite metasomatism of peridotite lithospheric mantle: Implications for diamond formation and carbonatite-kimberlite magmatism. Rus. Geol. Geophys. 2015, 56, 280-295. [CrossRef]

44. Agashev, A.M.; Ionov, D.A.; Pokhilenko, N.P.; Golovin, A.V.; Cherepanova, Y.; Sharygin, I.S. Metasomatism in lithospheric mantle roots: Constraints from whole-rock and mineral chemical composition of deformed peridotite xenoliths from kimberlite pipe Udachnaya. Lithos 2013, 160-161, 201-215. [CrossRef]

45. McDonough, W.F.; Sun, S. The composition of the earth. Chem. Geol. 1995, 120, 223-253. [CrossRef]

46. Aoki, K. Origin of phlogopite and potassic-richteritebearing peridotite xenoliths from South Africa. Contrib. Mineral. Petrol. 1975, 53, 145-156. [CrossRef]

47. Safonov, O.; Butvina, V.; Limanov, E. Phlogopite-Forming Reactions as Indicators of Metasomatism in the Lithospheric Mantle. Minerals 2019, 9, 685. [CrossRef]

48. Yudin, D.S.; Tomilenko, A.A.; Alifirova, T.A.; Travin, A.V.; Murzintsev, N.G.; Pokhilenko, N.P. Results of ${ }^{40}$ Ar $/{ }^{39}$ Ar Dating of Phlogopites from Kelyphitic Rims around Garnet Grains (Udachnaya-Vostochnaya Kimberlite Pipe). Dokl. Earth Sci. 2016, 469, 728-731. [CrossRef]

49. Brey, G.P. Fictive conductive geotherms beneath the Kaapvaal craton. In Proceedings of the 5th Intern Kimberlite Conference: Extended Abstracts; CPRM: Brasilia, Brazil, 1991; pp. 23-25.

50. Becker, H. Petrological constraints on the cooling history of high-temperature garnet peridotite massifs in lower Austria. Contrib. Mineral. Petrol. 1997, 128, 272-286. [CrossRef]

51. Brey, G.P.; Kohler, T.; Nickel, K.G. Geothermobarometry in Four-phase Lherzolites I. Experimental Results from 10 to 60 kb. J. Petrol 1990, 31, 1313-1352. [CrossRef] 
52. Brey, G.P.; Kohler, T. Geothermobarometry in four phase Iherzolites II. New thermobarometers. and practical assessment of existing thermobarometers. J. Petrol. 1990, 31, 1352-1378. [CrossRef]

53. MacGregor, I.D. The system $\mathrm{MgO}-\mathrm{Al}_{2} \mathrm{O}_{3}-\mathrm{SiO}_{2}$ : Solubility of $\mathrm{Al}_{2} \mathrm{O}_{3}$ in enstatite for spinel and garnet peridotite compositions. Am. Mineral. 1974, 59, 110-119.

54. Finnerty, A.A.; Boyd, F.R. Thermobarometry for garnet-periodotite xenoliths: A basis for upper-mantle stratigraphy. In Mantle Xenoliths; Nixon, P.H., Ed.; John Wiley and Sons: New York, NY, USA, 1987; pp. 381-402.

55. O'Neill, H.S.C.; Wood, B.J. An experimental study of Fe-Mg partitioning between garnet and olivine and its calibration as a geothermometer. Contrib. Mineral. Petrol. 1979, 70, 59-70. [CrossRef]

56. Grütter, H.S.; Latti, D.; Menzies, A. Cr-saturation arrays in concentrate garnet compositions from kimberlite and their use in mantle barometry. J. Petrol. 2006, 47, 801-820. [CrossRef]

57. Kennedy, C.S.; Kennedy, G.C. The Equilibrium Boundary Between Graphite and Diamond. J. Geophys. Res. 1976, 81, 2467-2470. [CrossRef]

58. Pollack, H.N.; Chapman, D.S. On the regional variation of heat flow, geotherms and lithospheric thickness. Tectonophysics 1977, 38, 279-296. [CrossRef]

59. Vishnevsky, A.A. Kelyphites on garnets in mantle xenoliths and kimberlites: Compositions, genesis, petrological implications. In Extended Abstracts of 5th International Kimberlite Conference, Araxa, Brasilia, June 1991; CRPM: Brasilia, Brazil, $1991 ;$ pp. 571-572.

60. Franz, L.; Brey, G.P.; Okrusch, M. Metasomatic reequilibration of mantle xenoliths from the Gibeon kimberlite province (Namibia). In International Kimberlite Conference: Extended Abstracts; United Institute of Geology, Geophysics and Mineralology, Siberian Branch of Russian Academy of Sciences: Novosibirsk, Russia, 1995; Volume 6, pp. 169-171.

61. Vyshnevsky, O.A. In-situ kelyphitisation of pyrope inclusion in chromspinel from kimberlites (kimberlite pipe "Pivdenna", Eastern Pryazovya). Notes Ukr. Mineral. Partnersh. 2009, 6, 107-112. (In Ukrainian)

62. Pokhilenko, N.P.; Sobolev, N.V.; Kuligin, S.S.; Shimizu, N. Peculiarities of distribution of pyroxenite paragenesis garnets in Yakutian kimberlite and some aspects of the Evolution of the Siberian Craton lithospheric mantle. In Proceedings of the 7th International Kimberlite Conference, Cape Town, South Africa, 11-17 April 1998; Red Roof Design: Cape Town, South Africa, 1999; Volume 2, pp. 689-698.

63. Misra, K.C.; Anand, M.; Taylor, L.A.; Sobolev, N.V. Multi-stage metasomatism of diamondiferous eclogite xenoliths from the Udachnaya kimberlite pipe, Yakutia, Siberia. Contrib. Mineral. Petrol. 2004, 146, 696-714. [CrossRef]

64. Liu, Y.; Taylor, L.A.; Sarbadhikari, A.B.; Valley, J.W.; Ushikubo, T.; Spicuzza, M.J.; Kita, N.; Ketchum, R.; Carlson, W.; Shatsky, V.S.; et al. Metasomatic origin of diamonds in the world's largest diamondiferous eclogite. Lithos 2009, 112, 1014-1024. [CrossRef] 